\title{
Functionality of the storage proteins in gluten-free cereals and pseudocereals in dough systems
}

John R.N. Taylor ${ }^{1,4}$, Janet Taylor ${ }^{1}$, Osvaldo H. Campanella ${ }^{2}$ and Bruce R. Hamaker ${ }^{3}$

$1_{\text {Institute for Food, Nutrition and Well-being and Department of Food Science, University of Pretoria, }}$ Private Bag X20, Hatfield 0028, South Africa

${ }^{2}$ Department of Agricultural and Biological Engineering, 745 Agriculture Mall Drive, Purdue University, West Lafayette, Indiana, 47907, USA

${ }^{3}$ Department of Food Science, 745 Agriculture Mall Drive, Purdue University, West Lafayette, Indiana, 47907, USA

${ }^{4}$ Corresponding author: Tel +2712 4204296, Fax +2712 4202839. E-mail address:

john.taylor@up.ac.za

Key words: beta-sheet, co-protein, gluten-free, zein

Abbreviations: CLSM, confocal laser scanning microscopy; G', shear storage modulus; G", shear loss modulus; HMW-GS, high molecular weight-glutenin subunits; SEM, scanning electron microscopy; SAOS, small amplitude oscillatory test; $T_{g}$, glass transition temperature 


\section{ABSTRACT}

The dough functionality of the storage proteins in "gluten-free" grains has been studied for almost 25 years. Zein, maize prolamin, when isolated as $\alpha$-zein can form a wheat gluten-like visco-elastic dough when mixed with water above its glass transition temperature. There is good evidence that its dough-forming properties are related to a change in protein conformation from $\alpha$-helix to $\beta$-sheet and association of the molecules into fibrils. Stabilisation of $\beta$-sheet structure and visco-elasticity can be enhanced by inclusion of a co-protein. No other isolated cereal or pseudocereal storage protein has been shown to form a visco-elastic dough. Many treatments have been applied to improve "gluten-free" storage protein functionality, including acid/base, deamidation, cross-linking by oxidising agents and transglutaminase, proteolysis, disulphide bond reduction and high pressure treatment. Such treatments have some limited positive benefits on batter-type dough functionality, but none is universally effective and the effects seem to be dependent on the composition and structure of the particular storage protein. Research into mutants where prolamin synthesis is altered appears to be promising in terms of improved dough functionality and scientific understanding. Research into how treatments affect the functionality and structure of isolated storage proteins from "gluten-free" grains other than maize is required. 


\section{Introduction}

Excellent progress has been made in the development of technology to produce gluten-free breads and other dough-based products with the aid of hydrocolloids and gums to improve dough viscoelasticity and gas-holding (Anton et al, 2008; Sciarini et al., 2010). An alternative approach involving improving the visco-elasticity and gas-holding properties of the storage proteins of gluten-free cereals has also been the subject of considerable research since the early 1990s (Lawton, 1992), but progress has been much slower (Erickson et al., 2012).

This approach of using the storage proteins of gluten-free cereals to support the creation of a stable, expanded leavened dough is nevertheless highly desirable. Many gluten-free bread products have poor nutritional quality in terms of proteins, micronutrients and dietary fibre due to them consisting primarily of purified carbohydrates (Matos and Rosell, 2015). Gluten-free dough-based products are generally also disproportionately costly (Singh and Whelan, 2011). Further, there is also a need for non-wheat and low-wheat (as opposed to gluten-free) bread. This is particularly the case in the developing countries of Asia and Africa where there is a huge increase in demand for bread and other Western-type foods, due to continuing high population growth and rapid urbanisation (Pingali, 2007). Cultivation of wheat and barley, which are temperate cereals, is not generally economically viable in these countries which lie in the tropics and semi-arid sub-tropics. Scientific developments in non-wheat dough systems, which parallel those that have taken place in brewing where cereals such as sorghum are now used extensively (Taylor et al., 2013b), would be highly beneficial to both persons who are intolerant to gluten and consumers in developing countries.

This review will focus on research being undertaken to improve the functionality of the storage proteins of maize, sorghum, the millets, oats, rice and the pseudocereals (buckwheat, amaranth and quinoa) in dough systems. Firstly, the composition and structural chemistry of these proteins in 
relation to those of wheat glutenin with respect to visco-elasticity will be briefly examined. Next, research into the dough functionality of the "gluten-free" storage proteins as isolated proteins will be reviewed. Then, the major section will review research into improvement of their dough functionality through chemical and physical modifications. After which, improvement through genetic modification of the proteins will be examined. Lastly, possible directions regarding practical application of the findings in bread-making and ongoing research will be considered.

\section{Composition and structure of the storage proteins of non-wheat cereals and pseudocereals}

To mimic the functional properties of gluten in non-gluten dough systems it is useful to understand how the storage proteins of non-wheat cereals and pseudocereals differ from wheat gluten in composition and structure. The functionality of gluten in wheat dough systems is complex, as recently reviewed by Juhász et al. (2015). As is well-known, gluten comprises monomeric gliadins which are responsible for dough viscosity and extensibility and polymeric glutenins, which critically are responsible for elasticity and strengthening the dough. In particular, the high molecular weight glutenin subunits (HMW-GS) are important in determining gluten elasticity (Shewry et al., 2002).

There are several valuable reviews concerning non-wheat grain storage proteins, including Shewry and Halford (2002), Lawton (2002) and Belton et al. (2006). Table 1 compares the composition and structure of the wheat high molecular weight glutenins with those of the prolamins of the tropical C4 cereals: maize sorghum, pearl millet and teff. The prolamins of maize and sorghum, zein and kafirin, respectively, like the wheat prolamins, are composed of a number of sub-classes (Shull et al., 1991). The polypeptide monomers are, however, all much smaller in size than the wheat HMW-GS, but like the HMW-GS they polymerise through disulphide cross-linking, due to the high cysteine content of the $\beta$ - and $\gamma$-sub-classes. The secondary structures of zein and kafirin are predominately $\alpha$-helical and tightly folded into a hairpin or rod-like structure , rather than consisting of more open 
Table 1

Composition and structures of maize, sorghum, pearl millet and teff prolamins in comparison with wheat high molecular weight glutenin subunits

\begin{tabular}{|c|c|c|c|c|c|c|c|c|}
\hline Species & $\begin{array}{l}\text { Storage } \\
\text { proteins }\end{array}$ & $\begin{array}{c}\% \text { of } \\
\text { total } \\
\text { prola } \\
\text { min } \\
\text { fractio } \\
n\end{array}$ & Polymerisation & $\begin{array}{c}\text { Subunit } \\
\text { molecular } \\
\text { weight (kDa) }\end{array}$ & $\begin{array}{l}\text { Major amino } \\
\text { acid } \\
\text { composition }\end{array}$ & $\begin{array}{l}\text { Structural model and } \\
\text { secondary structure }\end{array}$ & $\begin{array}{l}\text { Hydrophobic } \\
\text { ity }\end{array}$ & Refs \\
\hline Wheat & $\begin{array}{l}\text { HMW } \\
\text { glutenin } \\
\text { subunits }\end{array}$ & $6-12$ & $\begin{array}{l}\text { Macro } \\
\text { polymers-linked } \\
\text { end to end by } \\
\text { disulphide } \\
\text { bonding }\end{array}$ & $65-90$ & $\begin{array}{l}\text { Glutamine, } \\
\text { proline, } \\
\text { glycine } \\
\text { cysteine }\end{array}$ & $\begin{array}{l}\text { Extensive repeat sequences } \\
\text { based on proline-rich and } \\
\text { glutamine rich motifs } \\
\text { Rod shaped, } \alpha \text { - helical at } \mathrm{N} \text { - and } \\
\mathrm{C} \text { - terminal domains, central } \\
\text { region of loose spirally repeated } \\
\beta \text {-turns }\end{array}$ & $\begin{array}{l}\text { Less } \\
\text { hydrophobic } \\
\text { than either } \\
\text { kafirin or } \\
\text { zein (Belton } \\
\text { et al., 2006) }\end{array}$ & $\begin{array}{l}\text { Shewry and } \\
\text { Tatham (1990) }\end{array}$ \\
\hline Maize & $\alpha$-zein & 80 & $\begin{array}{l}\text { Limited } \\
\text { polymerisation } \\
\text { through } \\
\text { disulphide } \\
\text { bonding with } \\
\text { other } \beta \text { - and } \gamma \text { - } \\
\text { zein }\end{array}$ & 19 and 22 & $\begin{array}{l}\text { Glutamine, } \\
\text { leucine, } \\
\text { cysteine, } \\
\text { proline }\end{array}$ & $\begin{array}{l}\text { 40-60\% } \alpha \text {-helix (Argos et al., } \\
\text { 1982; Tatham et al., 1993, } \\
\text { Forato et al., 2004, Cabra et al., } \\
\text { 2005) 7-19.5\% } \beta \text {-sheet (Cabra et } \\
\text { al., 2005). Classic Argos model } \\
\text { based on } 9 \text { anti-parallel } \alpha \text { - } \\
\text { helices within a distorted } \\
\text { cylinder (Argos et al., 1982). } \\
\text { Modified models based on } \\
\text { extended hairpin, rod or ribbon- } \\
\text { like structures } 17 \text { x } 4.5 \text { x } 1.2 \text { nm, } \\
\text { with clearly defined hydrophilic } \\
\text { and hydrophobic domains } \\
\text { (Matsushima et al., 1997; Bugs } \\
\text { et al., 2004; Forato et al., 2004; } \\
\text { Momany et al., 2006) }\end{array}$ & $\begin{array}{l}\text { More } \\
\text { hydrophobic } \\
\text { than gluten } \\
\text { but less } \\
\text { hydrophobic } \\
\text { than kafirin, } \\
\text { has some } \\
\text { hydrophilic } \\
\text { properties } \\
\text { (Belton et al., } \\
\text { 2006) }\end{array}$ & $\begin{array}{l}\text { Shewry and } \\
\text { Tatham (1990) } \\
\text { Colman and } \\
\text { Larkins (1999) }\end{array}$ \\
\hline
\end{tabular}




\begin{tabular}{|c|c|c|c|c|c|c|c|c|}
\hline & $\beta$-zein & $7-8$ & $\begin{array}{l}\text { Polymerise } \\
\text { through } \\
\text { disulphide } \\
\text { bonding }\end{array}$ & 14 and 16 & $\begin{array}{l}\text { Glutamine, } \\
\text { alanine, } \\
\text { methionine, } \\
\text { leucine, } \\
\text { cysteine }\end{array}$ & $\begin{array}{l}\text { Mainly } \beta \text {-sheet, } \beta \text {-turn and } \\
\text { random coil (Shewry and } \\
\text { Tatham, 1990). No structural } \\
\text { model. }\end{array}$ & & \\
\hline & $\gamma$-zein & $9-12$ & $\begin{array}{l}\text { Polymerise } \\
\text { through } \\
\text { disulphide } \\
\text { bonding }\end{array}$ & 28 & $\begin{array}{l}\text { Proline, } \\
\text { glutamine, } \\
\text { leucine, } \\
\text { histidine, } \\
\text { cysteine }\end{array}$ & $\begin{array}{l}\text { Only } \gamma \text {-zein contains repeated } \\
\text { amino acid sequence, } \\
\text { hexapeptide repeat of Pro-Pro- } \\
\text { Pro-Val-His-Leu. } 19-32 \% \alpha \text {-helix, } \\
11-32 \% \beta \text { - sheet (Wu et al., } \\
1983 \text { ). No structural model. }\end{array}$ & & \\
\hline & $\delta$ - zein & & & 14 and 21 & $\begin{array}{l}\text { Methionine } \\
\text { rich }\end{array}$ & & & \\
\hline \multirow[t]{4}{*}{ Sorghum } & $\alpha$-kafirin & 80 & $\begin{array}{l}\text { Polymerise } \\
\text { through } \\
\text { disulphide } \\
\text { bonding with } \\
\text { other } \beta \text { - and } \gamma \text { - } \\
\text { kafirin }\end{array}$ & $23-25$ & $\begin{array}{l}\text { Glutamine, } \\
\text { leucine, } \\
\text { alanine, } \\
\text { proline, } \\
\text { cysteine }\end{array}$ & \multirow{4}{*}{$\begin{array}{l}\text { Total kafirin (containing all } \\
\text { prolamin sub-units) similar } \\
\text { secondary structure contents to } \\
\alpha \text { - zein, } 40 \%-60 \% \alpha \text { - helix } \\
\text { (Belton et al., } 2006 \text { ) } \\
\text { No structural models for kafirin } \\
\text { or any of its sub-classes but } \\
\text { thought to be similar to zein } \\
\text { Only } \gamma \text {-kafirin contains repeated } \\
\text { amino acid sequence, } \\
\text { hexapeptide repeat of Pro-Pro- } \\
\text { Pro-Val-His-Leu }\end{array}$} & \multirow{4}{*}{$\begin{array}{l}\text { More } \\
\text { hydrophobic } \\
\text { than gluten } \\
\text { and zein, has } \\
\text { some } \\
\text { hydrophilic } \\
\text { properties } \\
\text { but is less } \\
\text { hydrophilic } \\
\text { than zein or } \\
\text { gluten } \\
\text { (Belton et al., } \\
\text { 2006) }\end{array}$} & \multirow[t]{4}{*}{$\begin{array}{l}\text { Shull et al. } \\
\text { (1991) } \\
\text { Watterson et al. } \\
(1993) \\
\text { Belton et al. } \\
(2006)\end{array}$} \\
\hline & $\beta$-kafirin & $7-8$ & $\begin{array}{l}\text { Polymerise } \\
\text { through } \\
\text { disulphide } \\
\text { bonding }\end{array}$ & $16-20$ & $\begin{array}{l}\text { Proline, } \\
\text { glutamine, } \\
\text { alanine, } \\
\text { leucine, } \\
\text { methionine, } \\
\text { cysteine }\end{array}$ & & & \\
\hline & $\nu$ - kafirin & $9-12$ & $\begin{array}{l}\text { Polymerise } \\
\text { through } \\
\text { disulphide } \\
\text { bonding }\end{array}$ & 28 & $\begin{array}{l}\text { Proline, } \\
\text { glutamine, } \\
\text { histidine, } \\
\text { cysteine } \\
\end{array}$ & & & \\
\hline & $\delta$ - kafirin & & & & $\begin{array}{l}\text { Methionine } \\
\text { rich }\end{array}$ & & & \\
\hline
\end{tabular}




\begin{tabular}{|l|l|l|l|l|l|l|l|}
\hline $\begin{array}{l}\text { Pearl } \\
\text { millet }\end{array}$ & Pennisetin & 40 & & $\begin{array}{l}22 \text { and } 20 \\
\text { and } 10\end{array}$ & $\begin{array}{l}\text { Glutamine, } \\
\text { alanine, } \\
\text { leucine }\end{array}$ & $\begin{array}{l}\text { 72\% } \alpha \text {-helix, 15\% } \beta \text {-turns and } \\
\text { 9\% } \beta \text { - sheet. Similar to } \alpha \text {-zein, } \\
\text { but slightly smaller, 14 nm } \\
\text { ribbons of folded } \alpha \text {-helical } \\
\text { segments. }\end{array}$ & $\begin{array}{l}\text { Bugs et al. } \\
(2004) \\
\text { Shewry (2002) }\end{array}$ \\
\hline & & & Dimers & $49-51$ & & & \\
\hline Teff & Prolamins & & & 22 and 25 & $\begin{array}{l}\text { Glutamine, } \\
\text { proline, } \\
\text { valine, } \\
\text { leucine, } \\
\text { alanine, } \\
\text { isoleucine, } \\
\text { phenylalanin } \\
\text { e }\end{array}$ & $\begin{array}{l}\text { Single dominant sequence, high } \\
\text { degree of homology with } \alpha- \\
\text { prolamins of maize and } \\
\text { sorghum }\end{array}$ & $\begin{array}{l}\text { Tatham et al. } \\
\text { (1996) }\end{array}$ \\
\hline
\end{tabular}


Table 2

Composition of and structures of rice, oats, quinoa, amaranth and buckwheat storage proteins

\begin{tabular}{|c|c|c|c|c|c|c|}
\hline Species & $\begin{array}{l}\text { Storage } \\
\text { proteins }\end{array}$ & $\begin{array}{c}\text { \%of } \\
\text { total } \\
\text { storage } \\
\text { protein } \\
\text { fraction }\end{array}$ & $\begin{array}{l}\text { Polymerisation, structural } \\
\text { model and secondary } \\
\text { structure }\end{array}$ & $\begin{array}{c}\text { Subunit } \\
\text { molecular } \\
\text { weight (kDa) }\end{array}$ & $\begin{array}{l}\text { Major amino acid } \\
\text { composition }\end{array}$ & Refs \\
\hline \multirow[t]{3}{*}{ Rice } & Glutelin & $66-78$ & $\begin{array}{l}\text { Not soluble in dilute salt } \\
\text { solutions so classically } \\
\text { defined as glutelins but } \\
\text { actually belong to } 11-12 \mathrm{~S} \\
\text { storage globulins family, } \\
\text { related to legumin type } \\
\text { globulins }\end{array}$ & & $\begin{array}{l}\text { Rich in glutamic } \\
\text { acid/glutamine, aspartic } \\
\text { acid and asparagine, } \\
\text { glycine and alanine, } \\
\text { poor in tryptophan, } \\
\text { methionine and } \\
\text { histidine }\end{array}$ & $\begin{array}{l}\text { Shewry and Halford (2002) } \\
\text { Wen and Luthe (1985) }\end{array}$ \\
\hline & $\alpha-$ & & \multirow[b]{2}{*}{$\begin{array}{l}\text { Polymerise by disulphide } \\
\text { bonding and hydrophobic } \\
\text { interactions to form very } \\
\text { large macromolecular } \\
\text { complexes ( } 64-500 \mathrm{kD}) \text {. } \\
\text { Insoluble in water due to } \\
\text { high levels of hydrophobic, } \\
\text { hydrogen and disulphide } \\
\text { bonding }\end{array}$} & $30-39$ & Basic polypeptides & \multirow{2}{*}{$\begin{array}{l}\text { Utsumi (1992) } \\
\text { Shewry and Halford (2002) } \\
\text { Juliano (2007) }\end{array}$} \\
\hline & $\beta-$ & & & $19-25$ & Acidic polypeptides & \\
\hline Oats & $12 \mathrm{~S}$ globulin & $50-80$ & $\begin{array}{l}\text { Structurally similar to } 11 \mathrm{~S} \\
\text { globulins of legumes. } \\
\text { Oligomeric protein } \\
\text { quaternary structure } \\
\text { similar to legumins, exist as } \\
\text { hexamers }\end{array}$ & & & $\begin{array}{l}\text { Klose and Arendt (2012) } \\
\text { Shewry and Halford (2002) }\end{array}$ \\
\hline
\end{tabular}




\begin{tabular}{|c|c|c|c|c|c|c|}
\hline & $12 \mathrm{~S} \alpha-$ & & \multirow{2}{*}{$\begin{array}{l}\alpha \text { - and } \beta \text {-subclasses are } \\
\text { disulphide bonded in } \\
\text { native globulin, forming a } \\
\text { units of } 54 \text { kDa which make } \\
\text { up the hexamers }\end{array}$} & 33 & $\begin{array}{l}\text { Acidic polypeptide, rich } \\
\text { in aspartic and glutamic } \\
\text { acids }\end{array}$ & $\begin{array}{l}\text { Shotwell et al. (1990) } \\
\text { Klose and Arendt (2012) } \\
\text { Shewry and Halford (2002) } \\
\text { Burgess et al. (1983) }\end{array}$ \\
\hline & $12 S \beta$ & & & 23 & $\begin{array}{l}\text { Basic polypeptide, rich } \\
\text { in histidine, arginine } \\
\text { and lysine }\end{array}$ & $\begin{array}{l}\text { Shewry and Halford (2002) } \\
\text { Burgess et al. (1983) }\end{array}$ \\
\hline \multirow[t]{3}{*}{ Quinoa } & $\begin{array}{l}\text { 11S globulins } \\
\text { (chenopodin) }\end{array}$ & & & & & \\
\hline & $A$ & & $\begin{array}{l}\text { Disulphide bonded acidic } \\
\text { polypeptides. Similar to } \\
\text { other acidic subunits of } \\
\text { other } 11 \text { S seed globulins }\end{array}$ & $32-39$ & \multirow[t]{2}{*}{$\begin{array}{l}\text { High levels } \\
\text { aspartate/asparagine, , } \\
\text { arginine, serine, leucine } \\
\text { and glycine }\end{array}$} & \multirow[t]{2}{*}{ Brinegar and Goundan (1993) } \\
\hline & B & & $\begin{array}{l}\text { Disulphide bonded basic } \\
\text { polypeptides. Similar to } \\
\text { other basic subunits of } \\
\text { other } 11 S \text { seed globulins. }\end{array}$ & $22-23$ & & \\
\hline \multicolumn{7}{|l|}{ Amaranth } \\
\hline & $\begin{array}{l}\text { 11S globulins } \\
\text { (amarantin) }\end{array}$ & & \multirow{3}{*}{$\begin{array}{l}\text { Like other } 11 \text { S legumin. } \\
\text { High in } \beta \text {-sheet (71\%) ( } \beta \text { - } \\
\text { barrel), } \beta \text {-turn (15-22\%) } \\
\text { and } \alpha \text {-helix }(3-15 \%)\end{array}$} & & \multirow{3}{*}{$\begin{array}{l}\text { All amino acids present, } \\
\text { no particularly high } \\
\text { levels of individual } \\
\text { amino acids }\end{array}$} & \multirow{3}{*}{$\begin{array}{l}\text { Segura-Nieto et al. (1992) } \\
\text { Marcone and Yada (1998) } \\
\text { Barba de la Rosa et al. (1996) } \\
\text { Tandang-Silvas et al. (2012) }\end{array}$} \\
\hline & Acidic chain & & & 35 & & \\
\hline & Basic chain & & & 24 & & \\
\hline Buckwheat & 13S globulins & 33 & $\begin{array}{l}\text { Typical globulin structure, } \\
\text { similar to legumins, } \\
\text { consists six sub-units } \\
\text { comprising of large acid } \\
\text { ( } 32-43 \mathrm{kD}) \text { and small basic } \\
(20-23 \mathrm{kD}) \text { chains, } \\
\text { associated by disulphide } \\
\text { bonds }\end{array}$ & 280 & $\begin{array}{l}\text { High in } \\
\text { aspartate/asparagine, } \\
\text { glutamate/glutamine } \\
\text { and glycine }\end{array}$ & Radović et al. (1996) \\
\hline
\end{tabular}


spirals of $\beta$-turns like HMW-GS (Belton et al., 2006). Also, both zein and kafirin are considerably more hydrophobic than gluten.. Presumably as a consequence of their greater hydrophobicity and different secondary structure, zein and kafirin have a higher glass transition temperature $\left(T_{g}\right)$ than gluten (Taylor et al., 2013a). The prolamins of pearl millet, pennisetin, whilst less studied, are considered to be similar to $\alpha$-zein in structure (Bugs et al., 2004).

Table 2 summarises the properties of the storage proteins of rice and oats, and of the pseudocereals amaranth, quinoa and buckwheat. The major storage proteins of rice and oats are globulins, similar to those of legumes, and account for some $70-80 \%$ of the endosperm storage proteins (Shewry and Halford, 2002). Both are related to the 11-12S legumin type globulins. The rice glutelins comprise acidic and basic polypeptide chains linked by a single disulphide bond (Shotwell et al., 1990) and share similarities with HMW glutenins (Shewry and Halford, 2002). The oat globulins, like the legumins, form hexameric structures. The major storage proteins of pseudocereals are also similar to the legume proteins. They contain $2 \mathrm{~S}$ albumin and $11 \mathrm{~S}$ globulin storage proteins, with $7 \mathrm{~S}$ globulins present in buckwheat and amaranth. Those of amaranth have predominantly $\beta$-sheet structure with $\beta$-barrel conformation (Tandang-Silvas et al., 2012). The 11S type globulins of oats, rice and the pseudocereals polymerise by disulphide bonding.

It is clear that whilst the composition and structure of these storage proteins share some similarities with glutenin, in particular the extensive disulphide bonded polymerisation of zein and kafirin, there are important differences in terms of amino acid composition, sequence and secondary, tertiary and quaternary structure.

\section{Dough forming properties of non-wheat storage proteins}

\subsection{Isolation in protein bodies}


Zein, kafirin and pennisetin prolamins, presumably as a result of their relative hydrophobicity and disulphide bond cross-linking (Shewry, 2002; Belton et al., 2006), are isolated in protein bodies in the starchy endosperm cells of the mature grain (Adams et al., 1976). Likewise, the rice prolamins are isolated in Type I protein bodies (Saito et al., 2012) and the glutelins are isolated in Type II protein bodies (Yamagata et al., 1982) and in oats the globulin and prolamin storage proteins are co-located in the same protein bodies (reviewed by Shewry and Halford, 2002). The albumin and globulin storage proteins of the pseudocereals, amaranth (Coimbra and Salema, 1994), buckwheat (Elpidina et al., 1990) and quinoa (Prego et al., 1998) are also isolated in protein bodies. The localisation of storage proteins in discrete protein bodies in these "gluten-free" grains is unlike the situation in wheat where the glutenin and gliadin proteins form a continuous matrix around the starch granules within the cells of the mature starchy endosperm (reviewed by Shewry and Halford, 2002).

\subsection{Dough formation}

For zein, kafirin, pennisetin and the rice storage proteins to be functional in doughs, it is presumably necessary for the protein bodies to be disrupted during dough mixing and the proteins freed. However, disruption of the protein bodies has only been observed to happen in maize under conditions when high mechanical energy (specific mechanical energy of $\geq 100 \mathrm{~kJ} / \mathrm{kg}$ ) was applied using extrusion cooking (Batterman-Azcona et al., 1999) or roller flaking (Batterman-Azcona and Hamaker, 1998). Transmission electron microscopy indicated that the freed $\alpha$-zein may have formed fibrils (Batterman-Azcona et al., 1999). With oats and pseudocereals, the storage proteins are presumably readily freed from the protein bodies during dough-making due to their aqueous soluble nature (Schoenlechner et al., 2008). 
Lawton (1992) in seminal research showed that commercial zein, which is essentially only $\alpha$-zein (Lawton, 2002; Oom et al., 2008), formed a visco-elastic wheat flour-like dough when mixed with maize starch and the inclusion of dibutyl tartrate (as a plasticizer) at $25^{\circ} \mathrm{C}$ and above, and at $35^{\circ} \mathrm{C}$ in the absence of dibutyl tartrate. A visco-elastic dough could not be formed below $25^{\circ} \mathrm{C}$ and viscoelasticity was lost if the doughs were cooled below $25^{\circ} \mathrm{C}$. These temperatures were shown to relate closely to the $T_{g}$ of zein as a function of moisture content. It was further observed by scanning electron microscopy (SEM) that zein had formed an extensive network of fibres (fibrils). The author concluded that the visco-elasticity of zein was governed by its $T_{g}$ and that fibre formation was apparently responsible for the visco-elasticity of the zein-starch doughs. Such zein-starch doughs can also expand and hold gas (Sly et al., 2014; Berta et al., 2015). Dough viscosity has been found to be the major factor affecting gas bubble structure formation (Berta et al., 2015).

Oom et al. (2008) showed that kafirin (comprising $\alpha$ - and $\psi$-kafirin) plus starch in water mixtures would not form visco-elastic doughs, even at the elevated temperature of $55^{\circ} \mathrm{C}$ and with addition of lactic acid as a plasticizer. However, a "dough" could be formed with kafirin by plasticizing kafirin (which had been hydrated in water) into a resin using oleic acid in a 2:1 ratio (kafirin:oleic acid). At $22^{\circ} \mathrm{C}$, kafirin and commercial zein-oleic acid resins showed similar extensional viscosity and strain hardening as a gluten resin. However, the kafirin resin, unlike the gluten and zein resins, rapidly became stiff (Fig. 1). This was attributed to higher levels of disulphide bonding in the kafirin. In slight contrast, Schober et al. (2011) found that while relatively pure $\alpha$-zein isolated with 70\% ethanol readily aggregated into a visco-elastic dough at $40^{\circ} \mathrm{C}$, kafirin isolated using $83 \%$ isopropanol (apparently relatively pure $\alpha$-kafirin) could aggregate into cohesive mass in water at $55^{\circ} \mathrm{C}$, but kafirin isolated using the more hydrophilic $70 \%$ ethanol did not aggregate. However, the aggregated kafirin mass had very poor dough properties as it immediately became hard. The inclusion of $5 \%$ mercaptoethanol (as reducing agent) improved its properties somewhat, as the mass remained 

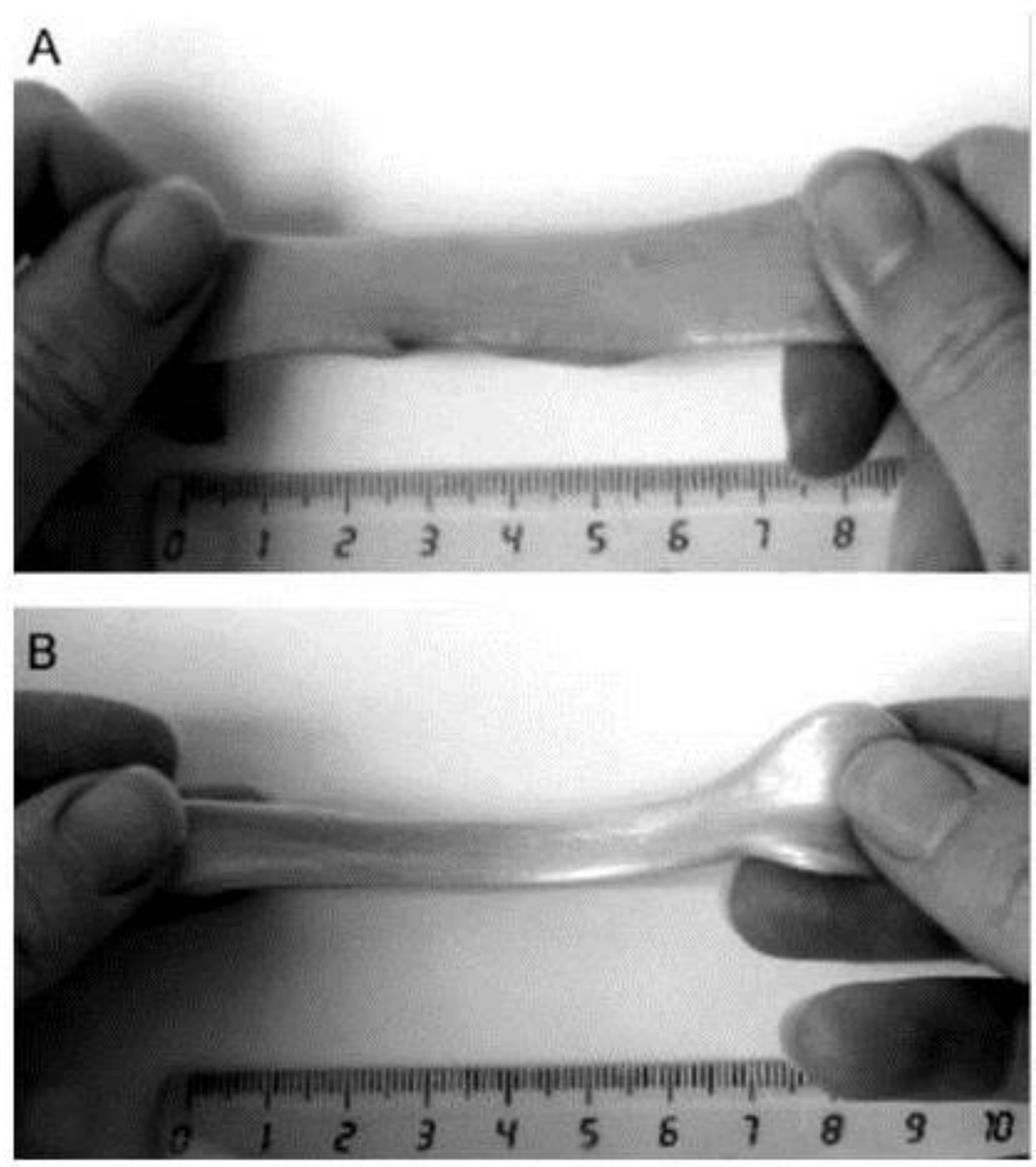

Fig. 1. Extensibility of (A) kafirin and (B) $\alpha$-zein resin doughs showing the stiffer nature of kafirin dough compared to $\alpha$-zein dough (Oom et al., 2008). Reproduced with the permission of the copyright holder. 
slightly extensible for a few minutes. The effect was attributed to breaking of disulphide bonds. The authors, on the basis of hydrophobicity of the various zein and kafirin sub-classes and the above described findings, suggested that hydrophobic interactions were the key to visco-elastic functionality of these proteins, and that disulphide bonds are undesirable. Smith et al. (2014) investigated the impact of various salts in the Hofmeister series on the formation of zein visco-elastic material (dough). It was found that $\mathrm{Nal}$ and $\mathrm{NaSCN}$ made the material softer and more extensible, while $\mathrm{NaCl}$ and $\mathrm{Na}_{2} \mathrm{SO}_{4}$ impacted negatively or even disrupted formation of the material, adding further support to the concept that zein visco-elastic properties result from non-covalent interactions.

Despite the fact that the storage proteins from all the gluten-free grains have been isolated and studied, there is essentially no evidence that any of them, apart from $\alpha$-zein, will form a gluten-like visco-elastic dough when mixed with water. Although, Avanza et al. (2005), for example,showed that amaranth protein produced an elastic gel when an aqueous protein dispersion was first heated to $70-95^{\circ} \mathrm{C}$ to denature the protein and then cooled.

In view of this, work to determine the molecular basis of $\alpha$-zein dough functionality will be discussed. This has focused on changes in protein secondary structure and has been explained in detail by Erickson et al. (2012).

\subsection{Influence of secondary structure on dough functionality}

Mejia et al. (2007) found that when commercial zein ( $\alpha$-zein) was mixed into a dough at $35^{\circ} \mathrm{C}$, above its $T_{g}$ in water, there was a substantial increase in $\beta$-sheet structure and concomitant decrease in $\alpha$ helical structure. This rearrangement was similar, but not identical, to that observed with wheat gluten where with extension there is an increase in $\beta$-sheet content and a concomitant decrease in $\beta$-turn content (Belton, 2005). However, when the temperature was reduced to $25^{\circ} \mathrm{C}$, the 
proportion of $\beta$-sheet structure in zein decreased substantially, which did not happen with gluten. Also, upon removal of shear stress, there was a rapid decrease in the proportion of $\beta$-sheet structure, which also did not happen with gluten. This led to Erickson et al. (2012) to theorise that the visco-elastic properties of zein were related to the formation of a $\beta$-sheet rich secondary structure, similar to that which is believed to be involved in the elasticity of the wheat HMW glutenin polymers (Belton, 2005). As noted, the major storage protein of amaranth, amarantin, an $11 \mathrm{~S}$ globulin also has mainly $\beta$-sheet structure (Tandang-Silvas et al., 2012) and it might be expected to have visco-elastic properties, which is not the case. However, since the structure in mainly intramolecular (not intermolecular) with $\beta$-barrel domains and is very stable, it has been suggested that this could not contribute to the required protein-protein interactions (Taylor et al., 2014).

Figure 2 shows the model developed by Wang and Padua (2012) to explain how zein ( $\alpha$-zein) selfassembles into nanostructures during film formation through a change from $\alpha$-helical to antiparallel $\beta$-sheet secondary structure. What has been proposed by Erickson et al. (2012) for when zein is mixed with water into a dough clearly parallels this. In the Wang and Padua model the antiparallel $\beta$-sheets form what they refer to as a "ribbon". Lai and Padua (1997) showed that films prepared from zein-oleic resins appeared to be made up of fibres (fibrils), which presumably are bundles of ribbons. The ribbons were also observed to form entanglements. Entanglements of fibrils have also been observed when kafirin was coacervated out of solution into microparticle-type materials (Taylor et al., 2009). These entanglements resembled an expanded foam (Fig. 3). Several researchers have observed fibrils in zein doughs by SEM and confocal laser scanning microscopy (CLSM) and suggested that fibril formation is a critical step in zein visco-elastic dough formation (Lawton, 1992; Schober et al., 2010; Sly et al., 2014).

Erickson et al. (2012) on the basis of their ongoing research also proposed that the inclusion of a small proportion of another protein in the dough such as HMW glutenin or even casein, which they 


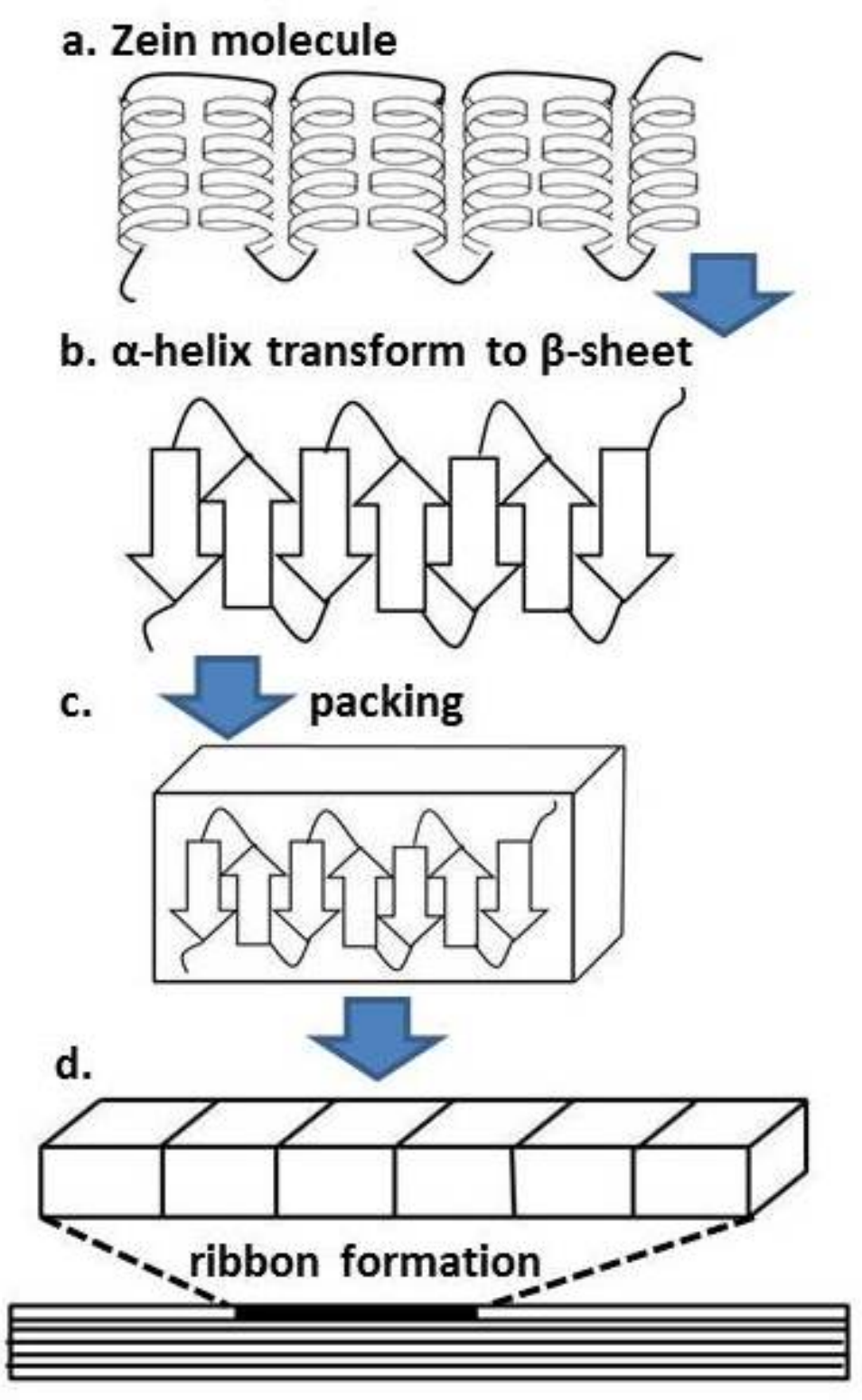

Fig. 2. Model for zein $\beta$-sheet ribbon formation according to Wang and Padua (2012). Adapted and redrawn. 


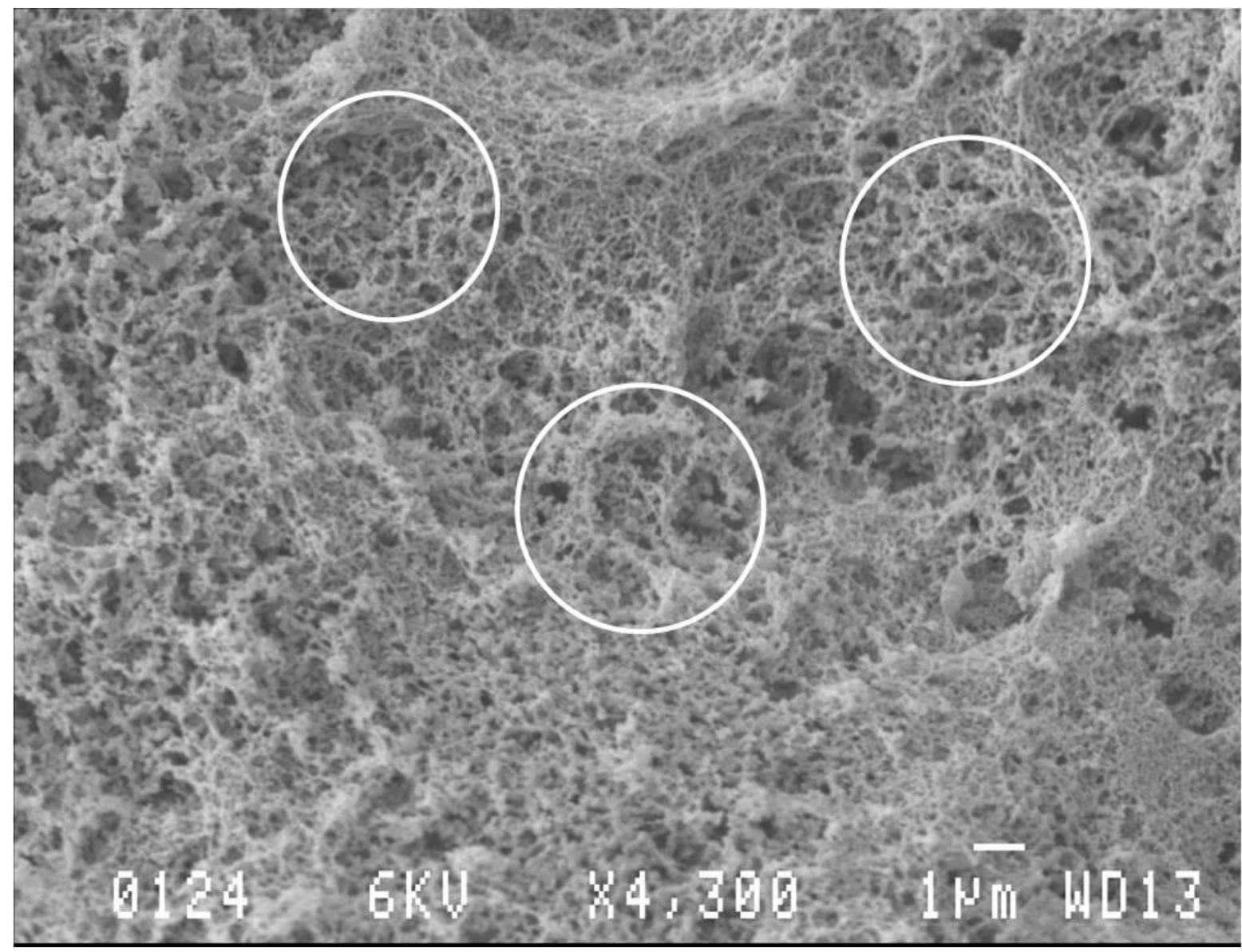

Fig. 3. SEM of entanglements of fibrils of kafirin coacervated from solution. Circles show foam-like structures. 
refer to as a "co-protein" is crucial to the stabilisation of the zein $\beta$-sheet structure, through the formation of fibrous $\beta$-sheet-rich networks. Marco and Rosell $(2008 a, b)$ showed that addition of various proteins (pea, soy, egg albumen and whey) to rice flour significantly changed the storage and viscous moduli of the doughs, possible evidence of a co-protein effect.

\section{The co-protein concept}

\subsection{Comparison of wheat gluten and maize zein}

For zein, as discussed, a structure with a viscoelastic behaviour can be obtained above its glass transition temperature at appropriate moisture levels (Lawton, 1992; Mejia et al., 2007). Yet, the structure is lost immediately after removal of the stress applied during mixing. At Purdue University, researchers pursued the hypothesis that the maize endosperm proteins are simply missing additional elastic HMW-GS that is in wheat, and that addition of a minor amount of this or another similar protein would confer viscoelasticity to the mixture. Mejia et al. (2012) showed that addition of such a co-protein, namely HMW-GS or casein (as a non-wheat protein), stabilized the viscoelasticity of the hydrated, heated (to $35^{\circ} \mathrm{C}$ ), and mixed maize zein, as well as held stable the $\beta$ sheet content after mixing had stopped. Furthermore, they hypothesized that both zein and gliadin are affected both in structure and function by their respective co-proteins. Understanding the properties of gliadin and zein systems with addition of the co-protein or plasticizers has provided a basic knowledge on how to functionalize zein and other zein-type cereal prolamins that might be used for the development of gluten-free systems (Erickson et al., 2012). The gliadin-zein hypothesis has been supported by a rheological and physicochemical study of the effect of HMW-GS addition to gliadin and zein composites (Fevzioglu et al., 2012), with an attempt made to relate structural and rheological data. 


\subsection{Rheological data}

Small Amplitude Oscillatory Shear Tests (SAOS)

The SAOS technique is ideal to characterize the structural properties of viscoelastic materials (Morrison, 2001). Typical data are shear storage modulus $\left(G^{\prime}\right)$ and shear loss modulus $\left(G^{\prime \prime}\right)$. $G^{\prime}$ is defined as the component of stress in phase with the strain and provides an indication of dough elasticity. On the other hand, $G^{\prime \prime}$ is related to the viscous nature of the material and represents the energy lost, and is as the component of stress that is $90^{\circ}$ out of phase with the strain (Campanella, 2011). Another material function used to describe the viscoelastic character of a material is the phase angle ( $\delta)$. A lower phase angle value indicates a dough with higher elasticity. In materials with an amorphous nature such has dough, it provides a better indication of the dough elasticity than the moduli defined above (Fevzioglu et al., 2012).

Based on their phase angle values, two different rheological behaviours were observed between pure proteins and composites containing the "co-protein" HMW-GS (Fig. 4). Doughs with high phase angle values, like zein and gliadin and also HMW-GS alone, were characterized as materials with a low elasticity (Fevzioglu et al., 2012). Conversely, doughs having low phase angle values, which included gluten and composites of gliadin with 20 and 10\% HMW-GS and zein with 10 and 5\% HMWGS, had high elasticity. As expected, the dough prepared with gluten showed the lowest phase angle value, suggesting it has a more elastic behaviour than the other materials. In particular, with zein, addition of a small amount of HMW-GS (5 and 10\%) caused a substantial change in its viscoelastic properties with phase angle values close to gluten. The finding that 5\% HMW-GS co-protein incorporation was nearly equal to $10 \%$ HMW-GS supported the view that the low amount of coprotein addition fundamentally changes to the structure and function of the larger "parent" prolamin protein. 


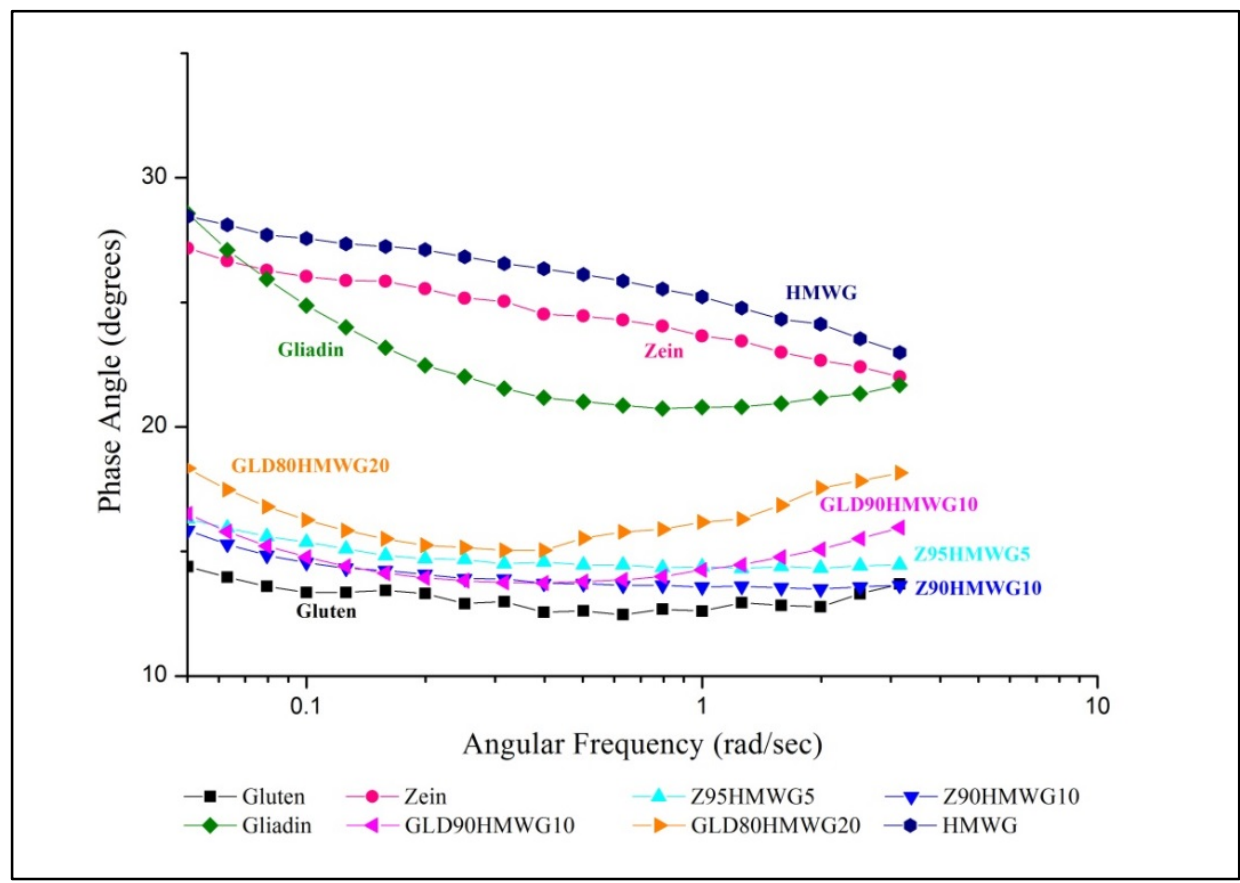

Fig. 4. Changes in phase angle values of zein dough systems with HMW-GS addition (adapted from Fevzioglu et. al., 2012). GLD90HMW-GS10 composite with 90\% gliadin and 10\% HMW-GS, GLD80HMWGS20 composite with $80 \%$ gliadin and $20 \%$ HMW-GS, Z90HMW-GS10 composite with $90 \%$ zein and $10 \%$ HMW-GS and Z95HMW-GS5 composite with 95\% zein and 5\% HMW-GS. All these percentages are based on the total amount of protein added to the sample. 
Large deformation rheological properties by lubricated squeezing flow test

Rheological measurements using large strains provide a better understanding of baking performance because the dough undergoes deformations/strains that are of the same order than those experienced during baking (Dobraszczyk and Morgenstern., 2003; Sliwinski et al., 2004; Dobraszczyk and Salmanowicz, 2008). The type of deformations to which doughs are subjected during the baking process of dough are biaxial extension and uniaxial elongation (Sliwinski et al., 2004). Thus, it is important to characterize the rheological properties of these composites. Lubricated squeezing flow viscometry is a rheological technique that applies biaxial deformation to a material (Campanella and Peleg, 2002)

This technique was employed to test the hypothesis that the addition of a co-protein (i.e. HMW-GS) enhances the viscoelastic properties of the gliadin and zein (Fevzioglu et al., 2012). Extensional viscosity that measures the resistance of the dough to be stretched was also used to assess the effect of the co-protein. Results showed that, at constant extensional rate, extensional viscosity of the gluten dough was higher than for the other dough types. It also showed significant strain hardening, a rheological property that is associated to good baking performance of dough (van Vliet, 2008). Extensional viscosities of all dough samples, except the HMW-GS dough, exhibited strain hardening (Fevzioglu et al., 2012).. The effect of the co-protein addition was observed by increase in extensional viscosities of zein and gliadin doughs. Notably, the impact of HMW-GS addition was more drastic on zein than on gliadin. Comparisons at higher strain rates showed that composites containing zein in the presence of the co-protein exhibited higher extensional viscosities. Overall, the rheological data gave good support to the concept of using a co-protein to improve the viscoelastic property of zein and hence other non-wheat cereal prolamins such as kafirin and pennisetin . 


\section{Chemical and physical modification}

A number of chemical (especially enzymic) and physical treatments have been applied to non-wheat proteins and their flours in order to modify their protein functional properties, with the aim of forming cohesive and elastic doughs. A weakness of much of this research is that the studies have generally involved flours, as opposed to isolated proteins. This approach is understandable since wheat flour, not isolated gluten, is normally used to make doughs and breads. Also, since essentially only zein is available commercially, the proteins have to be isolated and this can be technically difficult and may alter their properties. However, working with flours does make the understanding of how these "gluten-free" proteins function in dough systems difficult. Hence, in this review, research work into modification of isolated proteins will be discussed first where information is available, followed by studies involving modification of gluten-free flours.

\subsection{Acid/base treatments}

Acidification is widely used in wheat dough systems to modify dough rheology by increasing waterholding capacity with the aim of increasing shelf-life and also to improve product aroma profile (Houben et al., 2010). Acidification is achieved by sourdough fermentation or by acid addition or by a combination of both. These treatments have also been applied to gluten-free dough systems in attempts to improve the textural, nutritional and shelf-life properties of gluten-free breads.

Strong acid or alkali (0.5-2 M HCl and $\mathrm{NaOH})$ addition, with or without heat, to isolated Z19 $\alpha$-zein caused deamidation of the zein and partial unfolding of the protein resulting in improved emulsifying properties (Cabra et al., 2007). However, such severe conditions do not reflect what would happen in a food system. Zhang et al. (2011) examined the effects of milder acid and base treatments $(0.0005-0.002 \mathrm{HCl}$ and $\mathrm{NaOH})$ on commercial zein at $20^{\circ} \mathrm{C}$, below zein's $\mathrm{T}_{\mathrm{g}}$ in water. They found structural changes occurred under both acidic and basic conditions $(\mathrm{pH} 2.7$ and 12.5) 
compared to near neutral conditions. These changes involved a decrease in $\alpha$-helix, $\beta$-sheet and $\beta$ turns and were attributed to mild deamidation of glutamine residues, since there was no evidence of fragmentation or polymerisation of zein molecules by SDS-PAGE. Deamidation of glutamine by acid or base results in the formation of glutamate (Zhang et al., 2011), which has an additional third pKa of 4.07. The conformational changes in the zein resulted in decreased viscosity, elastic modulus and viscous modulus.

Mixing zein into a dough using weak organic acids such as lactic acid and acetic acid, as produced in sourdough fermentations, was found to result in highly extensible but weak doughs (Sly et al., 2014). Increasing the acid concentrations from $0.7 \%$ to $5.4 \%$ caused a progressive and substantial decrease in dough strength but with retention of dough cohesion. These changes in dough functional properties were thought to be due to the uniformity of the dough and linear orientation of zein fibrils as shown by CLSM. Secondary structural changes above the $T_{g}$ of zein in water showed that with increasing acid concentration there was an increase in proportion of $\alpha$-helix when compared to zein mixed with water. However, in all cases the proportion $\beta$-sheet structure was still high. When zein was mixed with maize starch or rice flour in the presence of the dilute acids $(\mathrm{pH}<4.0)$ cohesive doughs were formed. These doughs could hold air and inflate a small dough bubble by alveograph, although small tears in the bubble rapidly formed. CLSM of the stretched zein-rice flour doughs showed linearly oriented continuous fibrils, which enveloped the flour particles (Fig. 5).

When isolated oat globulins were treated with $\mathrm{NaOH}$ to give a pH 9.7 at 25,37 and $55^{\circ} \mathrm{C}$, insoluble aggregates formed at the lower temperatures and soluble aggregates at $55^{\circ} \mathrm{C}$ (Ma et al., 1990). Free sulphydryl content was found to decrease progressively with time at all temperatures and was attributed to disulphide bond formation. Surface hydrophobicity increased at $25^{\circ} \mathrm{C}$ but decreased at $37^{\circ} \mathrm{C}$. The changes were suggested to be due to protein conformational changes and partial denaturation of the proteins due to proteolysis by proteases co-extracted with the proteins. 

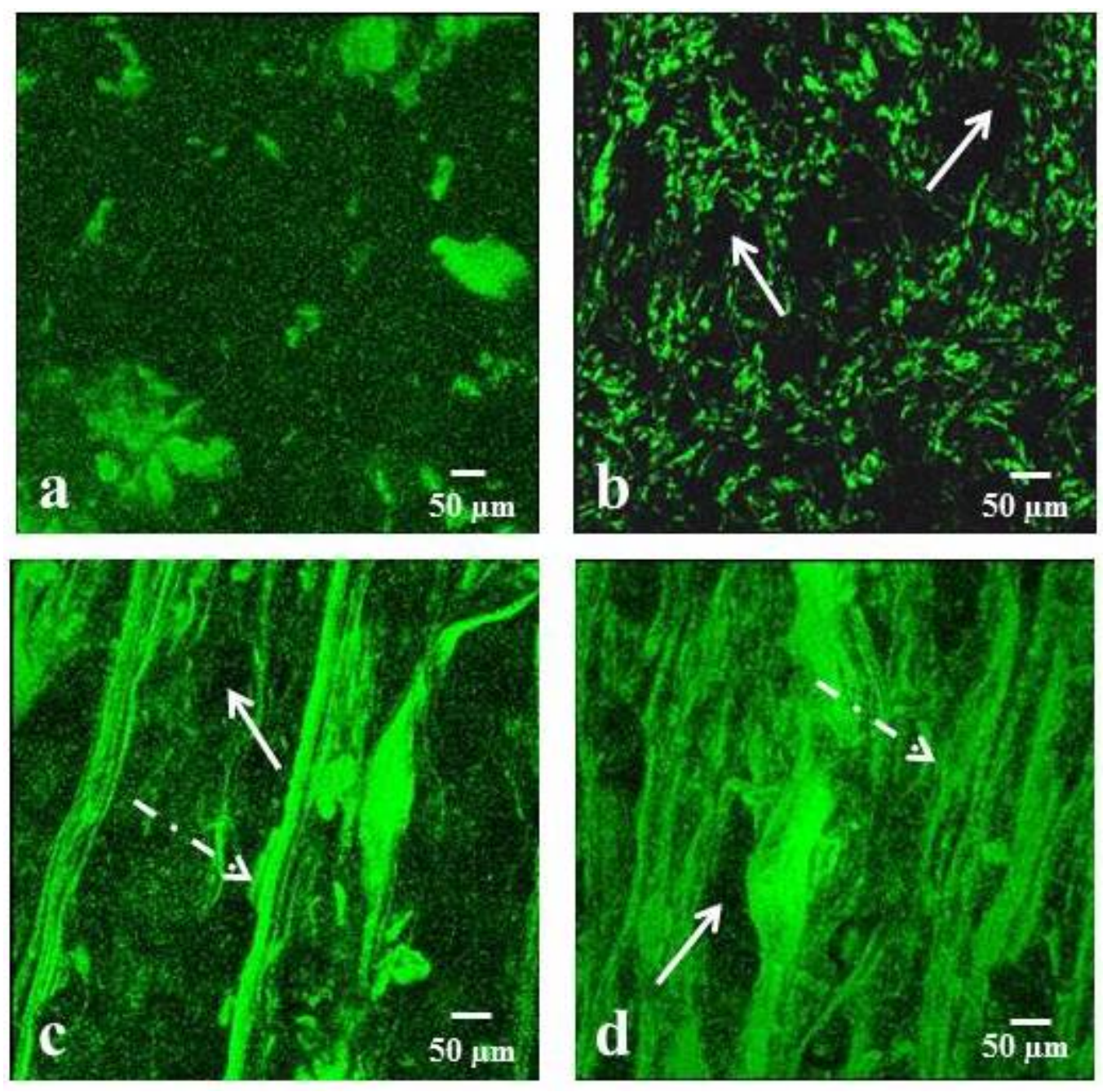

Fig. 5. CLSM of stretched zein-rice flour doughs (Sly et al., 2014). Doughs prepared with: a. distilled water at room temp.; b. distilled water at $40 \circ \mathrm{oC}$; c. $1.3 \%$ lactic acid at $40 \mathrm{oC}$; d. $5.4 \%$ lactic acid at $40 \mathrm{oC}$. Dashed arrows indicate oriented zein fibrils; solid arrows indicate rice flour particles. Reproduced with the permission of the copyright holder. 
When isolated amaranth proteins were exposed to extremes of $\mathrm{pH}$, they also underwent conformational changes and partial or total denaturation (Abugoch et al., 2010). Surface hydrophobicity was found to be lower at acid $\mathrm{pH}$ than at alkaline $\mathrm{pH}$. When amaranth flour doughs were acidified with lactic acid to a pH 4.4, the doughs were firmer and but not substantially more elastic than when no acid was present (Houben et al., 2010). Increasing the amount of acid used increased dough firmness further. It appeared that the added protons increased the binding capacity of the proteins in the dough.

\subsection{Oxidative cross-linking}

Oxidising enzymes such as glucose oxidase and laccase (diphenol oxidase) are used in wheat dough systems to increase dough strength and stability and hence increase bread volume and crumb softness and structure (Goesaert et al., 2005). In gluten-free research, such enzymes have been applied to oats to generate covalent linkages and positively influence the bread-making properties of flours (Flander et al., 2008, 2011; Renzetti et al., 2010). Tyrosinase, which specifically oxidises tyrosine to benzoquinone, cross-linked isolated oat globulins but not oat albumins or prolamins (Flander et al., 2011). The microstructure of tyrosinase cross-linked oat globulins showed aggregated globulins, which resulted in increased oat dough hardness. High levels of enzyme addition resulted in dough softening, attributed to xylanase and $\beta$-glucanase side activities in the tyrosinase preparation. This softening was insufficient to counteract the protein cross-linking caused by the tyrosinase, since the oat bread was still harder than the control. Tyrosinase did not affect the extensibility of the oat dough.

Renzetti et al. (2010) found that laccase increased loaf volume and decreased crumb hardness and chewiness of oat breads. The laccase affected oat dough rheology by increasing elasticity, which led to increased stability of batter films during expansion of gas cells. This prevented premature gas cell 
rupture. The ability of the batter to deform more easily probably led to improved bread properties. In addition, small protein aggregates in laccase bread crumb led to better bread-making performance. Improvements of dough rheology were also thought to be due $\beta$-glucanase side activities. In contrast, Flander et al. (2008) found that laccase treatment increased oat bread firmness. The authors found an increase the amount of middle-sized soluble proteins, (63-65 kDa) with a concomitant decrease in the number of smaller soluble proteins and no effect on oat globulins. They thought that the oat dough had sufficient free ferulic acid for laccase to form phenoxy radicals leading to disulphide bonds between proteins and low molecular weight thiols, resulting in an increase in oat bread firmness. Both research groups measured a reduction in the number of sulphydryl groups (Flander et al., 2008; Renzetti et al., 2010).

Glucose oxidase catalyses the oxidation of glucose to form gluconic acid and hydrogen peroxide. The hydrogen peroxide promotes inter- and intra-molecular disulphide cross-linking in wheat bread systems (Primo-Martin et al., 2003). When applied to gluten-free systems glucose oxidase treatment had different effects, depending on the type of gluten-free cereal (Renzetti et al., 2009a). Maize and sorghum breads showed improved loaf volumes and reduced collapsing of the loaf top, which was attributed to protein polymerisation, aggregated protein structures and enhanced batter elasticity. Positive effects on dough rheology, loaf volume and bread texture were found when rice flour was treated with glucose oxidase in the presence of hydoxypropyl methycellulose as a result of cross-linking of the proteins (Gujral and Rosell, 2004a). When oat flour was treated with glucose oxidase extensive protein polymerisation resulted in large globular protein aggregates as viewed by CLSM (Renzetti et al., 2010). These large protein aggregates were thought to cause detrimental effects on oat bread texture in the form of an increase in crumb hardness. However, the enzyme had no significant effect on the quality of buckwheat or teff breads (Renzetti et al., 2009a). 


\subsection{Transglutaminase mediated cross-linking and deamidation}

Transglutaminase catalyses the formation of $\varepsilon$-( $($-glutamyl)lysine cross-links in proteins (Ohtsuka et al., 2000) but can also deamidate glutamine in lysine-poor proteins such as the cereal prolamins (Larré et al., 1993). It has been widely investigated in gluten-free bread-making but often in combination with other treatments such as protein and hydrocolloid addition (Gujral and Rosell, 2004b; Moore et al., 2006; Marco and Rosell, 2008 a,b), which makes it difficult to establish whether the observed effects on bread quality are due to protein modification or the additives or a combination.

Concerning research on where transglutaminase was used as a sole treatment, buckwheat and brown rice batters showed significant increases in pseudoplastic behaviour and improved baking performance in terms of crumb structure and chewiness but not loaf volume, at high levels of enzyme addition, which were attributed to protein polymerisation (Renzetti el al., 2008a). Increases in crumb hardness, chewiness and decreased specific volumes, at high enzyme addition, were attributed to protein cross-linking. Oat and sorghum batters also showed increased pseudoplastic behaviour but this did not result in improved baking performance or textural properties. Maize batters showed a decrease in elastic properties and improved baking performance in terms of increased specific loaf volume, decreased crumb hardness and chewiness. The authors speculated that due to maize flour's low protein content and low lysine content, deamidation reactions were more prevalent than protein cross-linking. The deamidation reactions could have been responsible for the decrease in viscosity, facilitating expansion of the batter. Using CLSM, the authors observed formation of protein complexes due to transglutaminase action in the case of buckwheat and brown rice batters but no differences could be seen for sorghum, oat, teff or maize batters. This was probably because both glutamine and lysine are needed for transglutaminase cross-linking, and lysine was limiting. Huang et al. (2010) found increased visco-elasticity and enhanced thermal stability of oat doughs treated with transglutaminase, which they attributed to protein cross-linking. 
Enzyme accessibility to substrate and protein solubility have been identified as playing roles in transglutaminase cross-linking (Coussons et al., 1992; Kang et al., 1994). Thus, Renzetti et al. (2008a) concluded that the improved baking performance of buckwheat flours treated with transglutaminase was due to the high level of glutamine and lysine in the soluble protein fraction of the flour and also potentially the presence of more accessible enzyme binding sites than oat flours.

A detailed study of the effect of transglutaminase activity on protein fractions ( $2 \mathrm{~S}$ albumin, $13 \mathrm{~S}$ and $8 \mathrm{~S}$ globulin) of buckwheat flours showed that all the fractions were reactive with transglutaminase (Renzetti et al., 2008b). An increase in molecular weight of all the protein fractions and the formation of high molecular weight protein polymers were thought responsible for the improved flour functionality, resulting in improved baking characteristics. A study of the protein fractions of brown rice flour after transglutaminase treatment showed that the $\alpha$ - and $\beta$-glutenin subunits were the primary substrates for polymerisation into supramolecular structures (Renzetti et al., 2012). The brown rice globulin and albumin fractions did not aggregate, despite the high lysine content the albumins. Thus, the specificity of transglutaminase for brown rice glutenins was thought to be due to greater accessibility of the enzyme to their glutamine and lysine residues compared with the albumin and globulin fractions. Transglutaminase polymerisation also promoted new and stronger hydrophobic interactions between proteins in brown rice batters. This, along with transglutaminase polymerisation of the glutelin complexes, was thought to be responsible for the improved textural properties of transglutaminase treated brown rice breads (Renzetti et al., 2008a). The authors speculated that deamidation reactions could be responsible for the improved baking performance of maize flour treated with transglutaminase due to a decrease in batter viscosity facilitating expansion of the batter. 


\subsection{Specific deamidation}

Deamidation of isolated $\alpha$-zein using glutaminase was found to result in conformational changes (Yong et al., 2004). A slight decrease in both $\alpha$-helical and antiparallel $\beta$-sheet structure was accompanied by a concomitant increase in $\beta$-turn and random coil.). These changes weakened the ability of zein to aggregate and led to increased solubility and better emulsion properties. Increased protein solubility was also found when rice glutelin was deamidated when treated with glutaminase (Liu et al., 2011). Deamidation resulted in the breaking of hydrophobic, hydrogen and some intermolecular disulphide bonds and changed protein conformation from $\alpha$-helix to random coil and $\beta$-turns.

\subsection{Disulphide bond reduction}

In contrast to improving storage protein dough functionality by cross-linking, there have been a few investigations in the effects of addition of reducing agents to break disulphide bonding. Smith et al. (2014) working with isolated zein found that the reducing agent mercaptothanol had little effect on the ability of isolated zein to form a dough, supporting the authors' hypothesis that non-covalent interactions are involved in zein dough formation. In apparent contrast, Yano (2010) working with rice batter found that the reducing agent glutathione dramatically improved batter gas-holding and subsequent loaf volume. Glutathione was found to prevent the formation of disulphide bonded "macromolecular protein barrier". In contrast, Capuani et al. (2014) found no substantial effect of glutathione addition on brown (whole grain) rice and buckwheat batters or breads, and attributed the different findings to type of redox agent used and molecular oxygen concentrations.

\subsection{Protein hydrolysis}

The positive effects of lactic acid bacteria and sourdough fermentations on bread quality go far beyond those caused simply by acid production. Concerning protein effects, fermentation results in 
activation of endogenous flour proteases (Hüttner and Arendt, 2010), and where the fermentative bacteria have high reductive activity such as Weisella cibaria, increase the amount of free thiol groups (Capuani et al., 2013). According to Clarke et al. (2002) sourdough fermentation changes the dough $\mathrm{pH}$ slowly, passing through a range of $\mathrm{pH}$ optima for various proteases and other enzymes present in the dough system. This then results in changes to the protein and starch properties of the dough, which in turn affects the final dough functionality. Various workers have described resultant protein degradation, detected by CLSM or by capillary electrophoresis, brought about by sourdough fermentation of brown rice (Capuani et al., 2014), buckwheat (Capuani et al., 2014; Moroni et al., 2011; Wolter et al., 2014), sorghum (Schober et al., 2007; Wolter et al., 2014), maize, teff, oat and quinoa (Wolter et al., 2014). On isolation of dough proteins from sourdough fermented sorghum, Schober et al. (2007) found that proteases degraded proteins that were already soluble at the beginning of fermentation. The resulting smaller sized peptides $(<19 \mathrm{kDa})$ could no longer cross-link and so did not aggregate upon baking. According to Elkhalifa et al. (2006), the small peptide proteolysis products are taken up by the bacteria for growth. Degradation of the kafirin by proteases has been found to be limited due to its location in protein bodies (Elkhalifa et al., 2006; Schober et al. (2007). Proteolysis also contributes to bread flavour (Arendt et al., 2007). In the case of maize sourdoughs, endosperm protein matrix degradation by proteases was thought to allow partial starch hydrolysis and leaching of amylose, resulting in less elastic doughs which were able to trap and retain carbon dioxide in a cohesive dough (Falade et al., 2014). Sourdough fermentation of buckwheat flours degraded the globulin fractions of the flour releasing smaller polypeptides, thus weakening protein-protein and protein-starch interactions and possibly influencing network connectivity (Moroni et al., 2011).

Proteases have been used as additives to improve dough and bread quality in rice breads, resulting in increased loaf volume and softer crumb structure (Hamada et al., 2013; Kawamura-Konishi et al., 2013; Renzetti and Arendt, 2009b; Hatta et al., 2015) and lower staling rate (Kawamura-Konishi et 
al., 2013). The mechanism seems to involve the hydrolysis of natively present disulphide-linked macromolecular proteins, which form a barrier around the rice starch granules and limit the swelling of the starch (Renzetti and Arendt, 2009b). Examination of the effects of different types of proteases showed that metallo, cysteine and serine type proteases were more effective at improving rice bread quality than aspartyl proteases (Hatta et al., 2015). Limited hydrolytic activity by proteases on rice storage proteins has been considered sufficient for improving rice bread quality (Hamada et al., 2013; Kawamura-Konishi et al., 2013). However, Hatta et al. (2015) described an increase in smaller proteins derived from the degradation of $\alpha$ - and $\beta$-glutelin. They considered that these small proteins formed aggregates through disulphide cross-linking and hydrophobic interactions on kneading the rice batter after endo-type protein hydrolysis. The protein aggregates formed fine networks which retained carbon dioxide during fermentation and resulted in increase in loaf volume and decrease in crumb hardness.

Protease addition to buckwheat, sorghum, maize and teff flours resulted in no significant effects on loaf volume or crumb hardness for maize and teff (Renzetti and Arendt, 2009a). However, with sorghum a liquid-like batter was produced. As only slight differences in protein microstructure and protein profiles were observed, this indicated that limited protein hydrolysis had occurred. When baked, these batters showed increased loaf volume but reduced crumb cohesiveness. Buckwheat batters also showed decreased viscosity with protease treatment. Protein degradation to low molecular weight peptides was observed along with decreased protein continuity when the batters were examined by CLSM. Baking of buckwheat batters also resulted in increased loaf volumes but with the presence of a large hole in the centre of the loaf. Oat bread batter quality was found to be improved with protease addition in terms of batter softness and increased ability of the batter to deform and increased elasticity, resulting in increased specific volume and decreased crumb harness and chewiness of breads (Renzetti et al., 2010). These improvements were attributed to extensive 
protein hydrolysis by the protease and depolymerisation of $\beta$-glucan by $\beta$-glucanase side activities in the protease preparation.

\subsection{High pressure}

Very high pressure treatment ( $\geq 200 \mathrm{MPa}$ ) has been investigated as a method of improving glutenfree cereal batter functionality. Hüttner et al. (2009) found that the application of hydrostatic pressure ( $\geq 300 \mathrm{MPa}$ ) to oat batter (flour-water batter) induced the formation of urea-insoluble protein complexes and/or disulphide bonds. The pressure treatment also induced starch gelatinisation. High pressure treatment was also found to induce protein polymerisation with rice and teff batters through thiol group-sulphydryl group interchanges, but this did not occur with buckwheat batter (Vallons et al., 2011), presumably due to the low level of cysteine in buckwheat storage proteins. With sorghum batters, pressures $\leq 300 \mathrm{MPa}$ weakened the structure, due to protein polymerisation, whereas at pressures $>300 \mathrm{MPa}$ batter constancy increased due to pressure induced starch gelatinisation (Vallons et al., 2010). Breads with 2\% pressure-treated sorghum showed delayed staling but at $10 \%$ addition the breads had low volume and poor quality. Similarly, high pressure treatment ( $350 \mathrm{MPa}$ ) of several different cereal flour batters was found to have negative effects on important quality parameters of wheat plus gluten-free cereal composite breads (Angioloni and Collar, 2012). With oat-wheat composite bread, loaf volume was reduced and with sorghum- and finger millet-wheat composites, whilst there was no adverse effect on loaf volume, the staling kinetics of the breads were more rapid.

\section{Genetic modification of storage protein expression}

High protein digestibility sorghums have been developed using mutation breeding that have altered, folded (invaginated) shaped protein bodies, due to the $\gamma$-kafirins being located at the base of the 


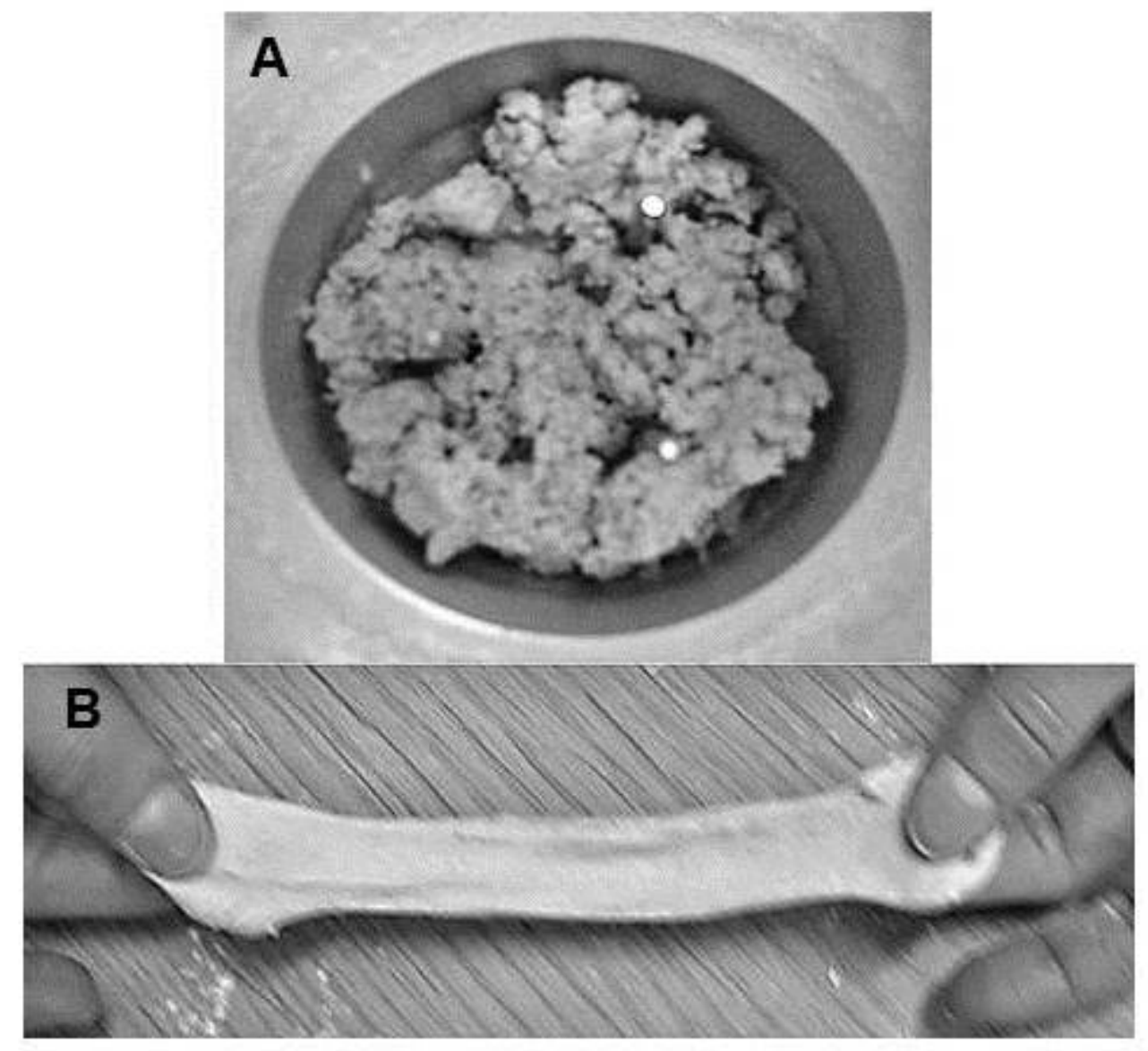

Fig. 6. Normal sorghum (left) and HDHL sorghum (right) flour doughs with $18 \%$ vital wheat gluten addition (Goodall et al., 2012). Reproduced with the permission of the copyright holder. 
invaginations, rather than around the protein body periphery (Oria et al., 2000). Goodall et al. (2012) showed that composites of high protein digestibility sorghum flour with added vital wheat gluten (18\%) formed a visco-elastic dough, whereas normal sorghum flour plus gluten did not (Fig. 6). They also showed that composite flour doughs of wheat and high protein digestibility sorghum had substantially greater resistance to extension than composites made with normal sorghum flour and that their breads were significantly larger. Kumar et al. (2012) concluded that the kafirin was freed from the protein bodies in these high protein digestibility sorghums and hence had the ability to form improved protein networks in wheat flour composites compared to normal sorghum.

Regarding the application of recombinant DNA technology (genetic engineering), the wheat HMWGS protein Glu-1Dx5 which notably increases dough strength (Blechl et al., 2007), has been expressed in maize (Sangtong et al., 2002). Recently, the expression of the Glu-1Dx5 protein in maize was examined in relation to its interaction with maize prolamins during maize endosperm development (Zhang et al., 2013). Its expression resulted in some distortion of protein body shape. Further, when the expression of $y$-zein was down-regulated, protein deformation was enhanced and a non-vitreous phenotype was produced. Apparently, the dough functionality of this phenotype was not investigated.

Down-regulating the expression of the cysteine-rich $\gamma$-kafirin in sorghum using recombinant DNA technology with the aim of reducing disulphide bond cross-linking and hence improving protein digestibility has been achieved in different studies. Da Silva et al. (2011a) and Grootboom et al. (2014) showed that co-suppression of the synthesis of $\alpha-, \gamma^{-}, \beta$ - and $\delta$-kafirins modified the structure of the protein bodies so that they had invaginations like those of the high protein digestibility mutant (Oria et al., 2000) and that they were less densely packed in the endosperm. These changes resulted in the endosperm structure becoming floury. Da Silva et al. (2011b) showed that these transgenic sorghums also had a much reduced proportion of disulphide bond cross-linked type 
kafirin. Dough-based baked products including biscuits and flatbreads of comparable quality to those from normal sorghum could be produced from these transgenic sorghums (Taylor and Taylor, 2011). However, their actual dough properties and leavened bread-making quality were not investigated. Kumar et al. (2012), in general agreement with the findings of Da Silva et al. (2011a) and Grootboom et al. (2014), showed that $\gamma$-kafirin suppression alone did not alone alter protein body structure, but attributed this to the silencing of a predicted $29 \mathrm{kDa} \alpha$-kafirin sub-class (presumably a cysteine-poor protein). With the aim of improving the roti (flatbread) making quality of sorghum, gene cassettes containing a wheat HMW-GS gene driven by the $\psi$-kafirin promoter have been constructed (Mishra et al., 2008). Latterly, similar gene cassettes have been used to express the wheat HMW-GSs Dy10/Dx5 in sorghum (Kumar et al., 2012). However, the impact of expression on wheat HMW-GS on sorghum dough and breadmaking quality has not as yet been determined.

There has been little research into genetic modification of storage proteins in the pseudocereals. Carrazco-Peňa et al. (2013) modified the primary structure of amaranth $11 \mathrm{~S}$ globulin with the aim of improving its functional properties, by insertion of four continuous methionine residues and expressing the gene in $E$. coli. The modification increased the hydrophobicity of the protein and resulting in it forming medium strength gels.

\section{Conclusions}

Despite nearly 25 years research into the functionality of "gluten-free" storage proteins in dough systems, only zein been shown to form a wheat gluten-like visco-elastic dough. Further, this is only when the zein has been extracted from the maize in the form of $\alpha$-zein, the most hydrophilic zein sub-class (Duodu et al., 2003). Clearly, mimicking gluten functionality is very challenging. While the co-protein concept has potential, this technology used alone has been unable to produce a 
comparable product to wheat bread. This probably related to the fact that zein is less hydrophilic than the wheat gluten proteins (Duodu et al., 2003; Shewry et al., 2003).

Perhaps, it will take a combination of technologies to produce gluten-free products that have all the attributes of wheat bread. Addition of a functional visco-elastic zein plus an appropriate non-gluten co-protein, together with hydrocolloids to a non-wheat cereal/pseudocereal flour may combine the desirable nutritional, protein-associated textural properties and high loaf volume associated with wheat bread.

With regard to improving the functionality of the storage proteins in oats, rice and the pseudocereals, enzyme treatments such as transglutaminase and proteolysis have some limited positive benefits on the functionality of the batter dough systems, but the effects seem to be grain protein type dependant. Hence, the best practical approach seems to be to use a combination of hydrocolloids and protein treatment to improve bread texture.

Regarding future research directions, the theory that a change in secondary structure from $\alpha$-helical to $\beta$-sheet is key to zein functionality appears to be well founded. However, as indicated, $\beta$-sheet structures are themselves highly complex (e.g. intra vs. inter, coils vs. barrels). At present we do not know enough about the nature of the $\beta$-structure in maize zein dough and what factors influence this and what prevents formation of doughs with sorghum kafirin, which is structurally very similar. Research into mutants where zein/kafirin synthesis is altered appears to be a promising avenue. Concerning other gluten-free grains, in order to improve our fundamental understanding of the observed effects on their flours of protein-altering treatments, there is a clear need to investigate how these treatments affect the functionality and structure of their isolated proteins. 


\section{References}

Abugoch, L.E., Martínez, N.E., Añón, M.C., 2010. Influence of pH on structure and function of amaranth (Amaranthus hypochondriacus) protein isolates. Cereal Chemistry 87, 448-453.

Adams, C.A., Novellie, L., Liebenberg, N.v.d.W., 1976. Biochemical properties and ultrastructure of protein bodies isolated from selected cereals. Cereal Chemistry 53, 1-12.

Angioloni, A., Collar, C., 2012. Effects of pressure treatment of hydrated oat, finger millet and sorghum flours on the quality and nutritional properties of composite wheat breads. Journal of Cereal Science 56, 713-719.

Anton, A.A., Artfield, S.D., 2008. Hydrocolloids in gluten-free breads: A review. International Journal of Food Sciences and Nutrition 59, 11-23.

Arendt, E. K., Ryan, L.A.M., Dal Bello, F., 2007. Impact of sourdough on the texture of bread. Food Microbiology 24, 165-174.

Argos, P., Pedersen, K., Marks, D., Larkins, B.A., 1982. A structural model for maize zein proteins. The Journal of Biological Chemistry 257, 9984-9990.

Avanza, V., Puppo, M.C., Añón, M.C., 2005. Rheological characterization of amaranth protein gels. Food Hydrocolloids 19, 889-898.

Barba de la Rosa, A.P., Herrera-Estrella, A., Utsumi, S., Paredes-López, O., 1996. Molecular characterisation, cloning and structural analysis of cDNA encoding amaranth globulin. Journal of Plant Physiology 149, 527-532.

Batterman-Azcona, S.J., Hamaker, B.R., 1998. Changes occurring in protein body structure and $\alpha$-zein during cornflake processing. Cereal Chemistry 75, 217-221.

Batterman-Azcona, S.J., Lawton, J.W., Hamaker, B.R., 1999. Effect of specific mechanical energy on protein bodies and $\alpha$-zeins in corn flour extrudates. Cereal Chemistry 76, 316-320.

Belton, P.S., 2005. New approaches to study the molecular basis of the mechanical properties of gluten. Journal of Cereal Science 41, 203-211. 
Belton, P.S., Delgadillo, I., Halford, N.G., Shewry, P.R., 2006. Kafirin structure and functionality. Journal of Cereal Science 44, 272-286.

Berta, M., Gmoser, R., Krona, A., Stading, M., 2015. Effect of viscoelasticity on foam development in zein-starch dough. LWT Food Science and Technology 63, 1229-1235.

Blechl, A., Lin, J., Nguyen, S., Chan, R., Anderson, O.D., Dupont. F.M., 2007. Transgenic wheats with elevated levels of Dx5 and/or Dy10 high-molecular-weight glutenin subunits yield doughs with increased mixing strength and tolerance. Journal of Cereal Science 45, 172-183.

Brinegar,C., Goundan, S., 1993. Isolation and characterization of chenopodin, the 11 S seed staoage protein of quinoa (Chenopodium quinoa). . Journal of Agricultural and Food Chemistry 41, 182-185. Bugs, M.R., Forato, L.A., Bortoleto-Bugs, R.K., Fischer, H., Mascarenhas, Y.P., Ward, R.J., Colnago, L.A., 2004. Spectroscopic characterisation and structural modeling of prolamin from maize and pearl millet. European Biophysics Journal 33, 335-343.

Burgess, S.R., Shewry, P.R., Matlashewski, G.J., Altosaar, I., Miflin, B.J., 1983. Characteristics of oat (Avena sativa L.) seed globulin. Journal of Experimental Botany 34, 1320-1332.

Cabra, V., Arreguin, R., Vazquez-Duhalt, R., Farres, A., 2007. Effect of alkaline deamidation on the structure, surface hydrophobicity and emulsifying properties of the Z19 $\alpha$-zein. Journal of Agricultural and Food Chemistry 55, 439-445.

Cabra, V., Arreguin, R., Galvez, A., Quirasco, M., Vazquez-Duhalt, R., Farres, A., 2005.

Characterization of a 19 kDa $\alpha$-zein of high purity. Journal of Agricultural and Food Chemistry 53, 725-729.

Campanella, O.H., 2011. Instrumental techniques for measurement of textural and rheological properties of foods. In: Cho, Y.-J., Kang, S. (Eds.), Emerging Technologies for Food Quality and Food Safety Evaluation. CRC Press Taylor and Francis Group, New York, pp. 6-54.

Campanella, O.H., Peleg, M., 2002. Squeezing flow viscometry for nonelastic semiliquid fluids-theory and applications. Critical Reviews in Food Science and Nutrition 42, 241-264. 
Capuani, A., Behr, J., Vogel, R.F., 2013. Influence of lactic bacteria on redox status and on proteolytic activity of buckwheat (Fagopyrum esculentum Moench) sourdoughs. International Journal of Food Microbiology 165, 148-155.

Capuani, A., Behr, J., Arendt, E.K., Vogel, R.F., 2014. Impact of 'oxidizing' and 'reducing' buckwheat sourdoughs on brown rice and buckwheat batter and bread. European Food Research and Technology 238, 978-988.

Carrazco-Peňa, L., Osuna-Casto, J.A., De Léon-Rodríguez, A., Maruyama, N., Toro-Vazquez, J.F., Morales-Rueda, J.A., Barba de la Rosa, A.P., 2013. Modification of solubility of heat-induced gelation of amaranth $11 \mathrm{~S}$ globulin by protein engineering. Journal of Agricultural and Food Chemistry 61, 3509-3516.

Coimbra, S., Salema, R., 1994. Amaranthus hypochondriacus: Seed structure and localization of seed reserves. Annals of Botany 74, 373-379.

Coleman, C.E., Larkins, B.A., 1999. Prolamins of maize. In: Shewry, P.R., Cassey, R. (Eds.), Seed Proteins. Kluwer Academic Publishers, Dordrecht, Netherlands, pp. 109-139.

Clarke, C., Schober, T., Arendt, E.K., 2002. The effect of a single strain and traditional mixed starter cultures on rheological properties of wheat dough and on bread quality. Cereal Chemistry 79, 640647.

Coussons, P., Price, N.C., Kelly, S.M., Smith, B., Sawyer, L., 1992. Factors that govern the specificity of transglutaminase-catalysed modification of proteins and peptides. Biochemical Journal 282, 929930.

Da Silva, L.S., Taylor, J. and Taylor, J.R.N., 2011a.Transgenic sorghum with altered kafirin synthesis: Kafirin solubility, polymerization and protein digestion. Journal of Agricultural and Food Chemistry 59, 9265-9270.

Da Silva, L.S., Jung, R., Zhao, Z., Glassman, K., Grootboom, A.W., Mehlo, L., O’Kennedy, M.M., Taylor, J., Taylor, J.R.N., 2011b. Effect of suppressing the synthesis of different kafirin sub-classes on grain 
endosperm texture, protein body structure and protein nutritional quality in improved sorghum lines. Journal of Cereal Science 54, 160-167.

Dobraszczyk, B.J., Morgenstern, M.P., 2003.Rheology and the breadmaking process. Journal of Cereal Science 38, 229-245.

Dobraszczyk, B.J., Smewing, J., Albertini, M., Maesmans, G., Schofield, J.D., 2003. Extensional rheology and stability of gas cell walls in bread doughs at elevated temperatures in relation to breadmaking performance. Cereal Chemistry 80, 218-224.

Duodo, K.G., Taylor, J.R.N., Belton, P.S., Hamaker, B.R., 2003. Factors affecting sorghum protein digestibility. Journal of Cereal Science 38, 117-131.

Elkhalifa, A.E.O., Bernhardt, R., Bonomi, F., lametti, S., Pagani, M.A., Zardi, M., 2006. Fermentation modifies protein/protein and protein/starch interactions in sorghum dough. European Food Research and Technology 222, 559-564.

Elpidina, E.N., Dunaevsky, Y.E., Belozerksy, M.A., 1990. Protein bodies from buckwheat seed cotyledons: Isolation and characteristics. Journal of Experimental Botany 41, 969-977.

Erickson, D.P., Campanella, O.H., Hamaker, B.R., 2012. Functionalizing maize zein in viscoelastic dough systems through fibrous $\beta$-sheet-rich protein networks: An alternative physicochemical approach to gluten-free breadmaking. Trends in Food Science and Technology 24, 74-81.

Erickson, D.P., Renzetti, S., Jurgens, A., Campanella, O H., \& Hamaker, B.R., 2014. Modulating state transition and mechanical properties of viscoelastic resins from maize zein through interactions with plasticizers and co-proteins. Journal of Cereal Science 60, 576-583.

Falade, A.T., Emmambux, M.N., Buys, E.M., Taylor, J.R.N., 2014. Improvement of maize bread quality through modification of dough rheological properties by lactic acid bacteria fermentation. Journal of Cereal Science 60, 471-476.

Fevzioglu, M., Hamaker, B.R., Campanella, O.H., 2012. Gliadin and zein show similar and improved rheological behavior when mixed with high molecular weight glutenin. Journal of Cereal Science 55, 265-271. 
Flander, L., Holopainen, U., Kruus, K., Buchert, J., 2011. Effects of tyrosinase and laccase on oat proteins and quality parameters of gluten-free oat breads. Journal of Agricultural and Food Chemistry 59, 8385-8390.

Flander, L., Rouau, X., Morel, M.H., Autio, K., Seppänen-Laakso, T., Kruus, K., Buchert, J., 2008.

Effects of laccase and xylanase on the chemical and rheological properties of oat and wheat doughs. Journal of Agricultural and Food Chemistry 56, 5732-5742.

Forato, L.A., Doriguetto, A.C., Fischer, H., Mascarenhas, Y.P., Craievich, A.F., Colnago, L.A., 2004. Conformation of the Z19 prolamin by FTIR, NMR, and SAXS. Journal of Agricultural and Food Chemistry 52, 2382-2385.

Goodall, M.A., Campanella, O.H., Ejeta, G., Hamaker, B.R., 2012. Grain of high digestibility, high lysine (HDHL) sorghum contains kafirins which enhance the protein network of composite dough and bread. Journal of Cereal Science 56, 352-357.

Goesaert, H., Brijs, K., Veraverbeke, W.S., Courtin, C.M., Gebruers, K., Delcour, J.A., 2005. Wheat flour constituents: How they impact bread quality and how to impact their functionality. Trends in Food Science and Technology 16, 12-30.

Grootboom, A.W., Mkhonza, N.L., Mbambo, Z., O’Kennedy, M.M, Da Silva, L.S., Taylor, J., Taylor, J.R.N., Chikwamba, R., Mehlo, L., 2014. Co-suppression of synthesis of major $\alpha$-kafirin sub-class together with $\psi$-kafirin-1 and $\gamma$-kafirin-2 required for substantially improved protein digestibility in transgenic sorghum. Plant Cell Reports 33, 521-537.

Gujral, H. S., Rosell, C. M., 2004a. Improvement of the breadmaking quality of rice flour by glucose oxidase. Food Research International 37, 75-81.

Gujral, H.S., Rosell, C.M., 2004b. Functionality of rice flour modified with a microbial transglutaminase. Journal of Cereal Science 39, 225-230.

Hatta, E., Matsumoto, K., Honda, Y., 2015. Bacillolysin, papain, and subtilisin improve the quality of gluten-free rice bread. Journal of Cereal Science 61, 41-47. 
Hamada, S., Suzuki, K., Aoki, N., Suzuki, Y., 2013. Improvements in the qualities of gluten-free bread after using a protease obtained from Aspergillus oryzae. Journal of Cereal Science 57, 91-97. Houben, A., Götz, H., Mitzscherling, M., Becker, T., 2010. Modification of the rheological behaviour of amaranth (Amaranthus hypochondriacus) dough. Journal of Cereal Science 51, 350-356. Huang, W., Li, L., Wang, F., Wan, J., Tilley, M., Ren, C., 2010. Effects of transglutaminase on the rheological and Mixolab thermomechanical characteristics of oat dough. Food Chemistry 121, 934939.

Hüttner, E.K., Arendt, E.K., 2010. Recent advances in gluten-free baking and the current status of oats. Trends in Food Science and Technology 21, 303-312.

Hüttner, E.K., Dal Bello, F., Poutanen, K., Arendt, E.K., 2009. Fundamental evaluation of the impact of high hydrostatic pressue on oat batters. Journal of Cereal Science 49, 363-370

Juhász, A., Békés, F., Wrigley, C.W., 2015. Wheat proteins. In: Ustunol, U,. (Ed.), Applied Food Protein Chemistry. Wiley Blackwell, Chichester, UK, pp. 219-305.

Juliano, B.O., 2007. Rice Chemistry and Quality. International Rice Research Institute, Manila. Kang, I.J., Matsumura, Y., Ikura, K., Motoki, M., Sakamoto, H., Mori, T., 1994. Gelation and gel properties of soyabean glycin in a transglutaminase-catalysed system. Journal of Agricultural and Food Chemistry 42, 159-165.

Kawamura-Konishi, Y., Shoda, K., Koga, H., Honda, Y., 2013. Improvement in gluten-free rice bread quality by protease treatment. Journal of Cereal Science $58,45-50$.

Klose, C., Arendt, E.K., 2012. Proteins in oats; their synthesis and changes during germination: A review. Critical Reviews in Food Science and Nutrition 52, 629-639.

Kumar, T., Dweikat, I., Sato, S., Ge, Z., Nersesian, N., Chen, H., Elthon, T., Bean, S., loerger, B.P., Tilley, M., Clemente, T., 2012. Modulation of kernel storage proteins in grain sorghum (Sorghum bicolor (L.) Moench). Plant Biotechnology Journal 10, 533-544.

Lai, H.-M., Padua, G.W., 1997. Properties and microstructure of plasticized zein film. Cereal Chemistry 74, 771-775. 
Larré, C., Chiarello, M., Blanloeil, Y., Chenu, M., Gueguen, J., 1993. Gliadin modifications catalyzed by guinea pig liver transglutaminase. Journal of Food Biochemistry 17, 267-282.

Lawton, J.W., 1992. Viscoelasticity of zein-starch doughs. Cereal Chemistry 69, 351-355.

Lawton, J.W. 2002. Zein: a history of processing and use. Cereal Chemistry 79, 1-18.

Liu, Y., Li, X., Zhou, X., Yu, J., Wang, F., Wang, J., 2011. Effects of glutaminase deamidation on the

structure and solubility of rice gluten. LWT-Food Science and Technology 44, 2205-2210.

Ma, C.-Y., Harwalker, V.R., Paquet, A., 1990. Physiochemical properties of alkali-treated oat globulin. Journal of Agricultural and Food Chemistry 38, 1707-1711.

Marco, C., Rosell, C.M., 2008a. Effect of different protein isolates and transglutaminase on rice flour properties. Journal of Food Engineering 84, 132-139.

Marco, C., Rosell, C.M., 2008b. Functional and rheological properties of protein enriched gluten free composite flours. Journal of Food Engineering 88, 94-103.

Marcone, M.F., Yada, R.Y., 1998. Structural analysis of globulins isolated from genetically different Amaranthus hybrid lines. Food Chemistry 61, 319-326.

Matos, M.E., Rosell, C.M., 2015. Understanding gluten-free dough for reaching breads with physical quality and nutritional balance. Journal of the Science of Food and Agriculture 95, 653-661.

Matsushima, N., Danno, G., Takezawa, H., Izumi, Y., 1997. Three-dimensional structure of maize $\alpha-$ zein proteins studied by small-angle X-ray scattering. Biochimica et Biopysica Acta 1339, 14-22. Mejia, C.D., Mauer, L.J., Hamaker, B.R,. 2007. Similarities and differences in secondary structure of viscoelastic maize $\alpha$-zein and wheat gluten proteins. Journal of Cereal Science 45,353-359. Mejia, C.D., Gonzalez, D C., Mauer, L.J., Campanella, O.H., Hamaker, B.R., 2012. Increasing and stabilizing $\beta$-sheet structure of maize zein causes improvement in its rheological properties. Journal of Agricultural and Food Chemistry 60, 2316-2321.

Mishra, A., Pandey, R., Bansal, S., Tomar, A., Khanna, V.K., Garg, G.K., 2008. Construction of gene cassette harboring HMW glutenin gene of wheat driven by $\mathrm{\gamma}$-kafirin promoter of sorghum. Acta Biologica Szegedeinsis 52, 277-282. 
Momany, F.A., Sessa, D.J., Lawton, J.W., Selling, G.W., Hamaker, S.A.H., Willett, J.L., 2006. Structural characterisation of $\alpha$-zein. Journal of Agricultural and Food Chemistry 54, 543-547.

Moore, M.M., Heinbockel, M., Dockery, P., Ulmer, H.M., Arendt, E.K., 2006. Network formation in gluten-free bread with application of transglutaminase. Cereal Chemistry 83, 28-36.

Moroni, A.V., Dal Bello, F., Zannini, E., Arendt, E.K., 2011. Impact of sourdough on buckwheat flour, batter and bread: Biochemical, rheological and textural insights. Journal of Cereal Science 54, 195202.

Morrison, F.A., 2001. Understanding Rheology. Oxford University Press, New York.

Ohtsuka, T., Sawa, A., Kawabata, R., Nio, N., Motoki, M., 2000. Substrate specificities of microbial transglutaminase for primary amines. Journal of Agricultural and Food Chemistry 48, 6230-6233.

Oom A., Pettersson, A., Taylor, J.R.N., Stading, M., 2008. Rheological properties of kafirin and zein prolamins. Journal of Cereal Science 47, 109-116.

Oria, M.P., Hamaker, B.R., Axtell, J.D., Huang, C., 2000. A highly digestible sorghum cultivar exhibits a unique folded structure of protein bodies. Proceedings of the National Academy of Sciences of the United States of America 97, 5065-5070.

Pingali, P., 2007. Westernization of Asian diets and the transformation of food systems: Implications for research and policy. Food Policy 32, 281-298.

Prego, I, Maldonado, S., Otegui, M., 1998. Seed structure and localization of reserves in Chemopodium quinoa. Annals of Botany $82,481-488$.

Primo-Martin, C., Valera, R., Martinez-Anaya, M.A., 2003. Effect of pentosanase and oxidases on the characteristics of doughs and the glutenin macropolymer. Journal of Agricultural and Food Chemistry $51,4673-4679$.

Radović, S.R., Maksimović, V.R., Varkonji-Gasić, I.E., 1996. Characterization of buckwheat seed storage proteins. Journal of Agricultural and Food Chemistry 44, 972-974. 
Renzetti, S., Arendt, E.K., 2009a. Effect of protease treatment on the baking quality of brown rice bread: From textural and rheological properties to biochemistry and microstructure. Journal of Cereal Science 50, 22-28.

Renzetti, S., Arendt, E. K., 2009b. Effects of oxidase and protease treatments on the breadmaking functionality of a range of gluten-free flours. European Food Research and Technology 229, 307317.

Renzetti, S., Dal Bello, F., Arendt, E.K., 2008a. Microstructure, fundamental rheology and baking characteristics of batters and breads from different gluten-free flours treated with a microbial transglutaminase. Journal of Cereal Science 48, 33-45.

Renzetti, S., Behr, J., Vogel, R.F., Arendt, E.K., 2008b. Transglutaminase polymerisation of buckwheat (Fagopyrum esculentum Moench) proteins. Journal of Cereal Science 48, 747-754.

Renzetti, S., Courtin, C.M., Delcour, J.A., Arendt, E.K., 2010. Oxidative and proteolytic enyme preparations as promising improvers for oat bread formulations: Rheological, biochemical and microstructural background. Food Chemistry 119, 1465-1473.

Renzetti, S., Behr, J., Vogel, R.F., Barbiroli, A., lametti, S., Bobomi, F., Arendt, E.K., 2012. Transglutaminase treatment of brown rice flour: A chromatographic, electrophoretic and spectroscopic study of protein modification. Food Chemistry 131, 1076-1085.

Saito, Y, Shigemitsu, T., Yamasaki, R., Sasou, A., Goto, F., Kishida, K., Kuroda, M, Tanaka, K, Morita, S., Satoh, S., Masumura, T., 2012. Formation mechanism of the internal structure of type I protein bodies in rice endosperm: relationship between the localization of the prolamin species and expression of individual genes. The Plant Journal 70, 1043-1055.

Sangtong, V., Moran, D.L., Chikwamba, R., Wang, K., Woodman-Clikeman, W., Long, M.J., Lee, M., Scott, M.P., 2002. Expression and inheritance of the wheat Glu-1DX5 gene in transgenic maize. Theoretical and Applied Genetics 105, 937-945. 
Schober, T.J., Bean, S.R., Boyle, D.L., 2007. Gluten-free sorghum bread improved by sourdough fermentation: Biochemical, rheological and microstructural background. Journal of Agricultural and Food Chemistry 55, 5137-5146.

Schober, T.J., Moreau, R.A., Bean, S.R., Boyle, D.L., 2010. Removal of surface lipids improves the functionality of commercial zein in viscoelastic zein-starch dough for gluten-free bread making. Journal of Cereal Science 52, 417-425.

Schober, T.J., Bean, S.R., Tilley, M., Smith, B.M., loerger, B.P., 2011. Impact of different isolation procedures on the functionality of zein and kafirin. Journal of Cereal Science 54, 241-249.

Schoenlechner, R., Siebenhandl, S., Berghofer, E., 2008. Pseudocereals. In: Arendt, E.K., Dal Bello, F. (Eds.), Gluten-free Cereal Products and Beverages. Academic Press, Burlington, MA, pp. 149-190. Sciarini, L.S., Ribotta, P.D., León, A.E., Pérez, G.T., 2010. Effect of hydrocolloids on gluten-free batter properties and bread quality. International Journal of Food Science and Technology 45, 2306-2312. Segura-Nieto, M., Vázquez-Sánchez, N., Rubio-Veláquez, H., Olguín-Martínez, L., Rodríguez-Nester, C., Herrera-Estrella, L., 1992. Characterization of amaranth (Amaranthus hypochondriacus L) seed proteins. Journal of Agricultural and Food Chemistry 40, 1553-1558.

Shewry, P.R., 2002. The major seed storage proteins of spelt wheat, sorghum, millets and pseudocereals. In: Belton, P.S., Taylor, J.R.N. (Eds.), Pseudocereals and Less Common Cereals: Grain Properties and Utilization Potential. Springer, Berlin, pp. 1-24.

Shewry, P.R., Halford, N.G., 2002. Cereal storage proteins: structures, properties and role in grain utilization. Journal of Experimental Botany 53, 947-958.

Shewry, P.R., Tatham, A. S. 1990. The prolamin proteins of cereal seeds: Structure and evolution. Biochemical Journal 267:1-12.

Shewry, P.R., Halford, N.G., Belton, P.S, Tatham, A.S., 2002. The structure and properties of gluten: an elastic protein from wheat grain. Philosophical Transactions: Biological Sciences 357, 133-142. Shewry, P.R., Halford, N.G., Tatham, A.S., Popineau, Y., Lafiandra, D., Belton, P.S., 2003. The high 
molecular weight subunits of wheat glutenin and their role in determining wheat processing properties. Advances in Food and Nutritional Research 45, 219-301.

Singh, J., Whelan, K., 2011. Limited availability and higher cost of gluten-free foods. Journal of Human Nutrition and Dietetics 24, 479-486.

Shotwell, M.A., Boyer, S.K., Chesnut, R.S., Larkins, B.A., 1990. Analysis of seed storage protein genes of oats. The Journal of Biological Chemistry 265, 9652-9658.

Shull, J.M., Watterson, J.J., Kirleis, A.W., 1991. Proposed nomenclature for the alcohol-soluble proteins (kafirins) of Sorghum bicolor (L. Moench) based on molecular weight, solubility and structure. Journal of Agricultural and Food Chemistry 39, 83-87.

Sliwinski, E.L., Kolster, P., van Vliet, T., 2004. On the relationship between large-deformation properties of wheat flour dough and baking quality. Journal of Cereal Science 39, 231-245.

Sly, A.C., Taylor, J., Taylor J.R.N. 2014 Improvement of zein dough characteristics using dilute organic acids. Journal of Cereal Science. 60, 157-163.

Smith, B.M., Bean, S.R., Selling, G., Sessa, D., Aramouni, F.D., 2014. Role of non-covalent interactions in the production of visco-elastic material from zein. Food Chemistry 147, 230-238.

Tandang-Silvas, M.R., Cabanos, C.S., Carrazco Peña, L.D., De La Rosa, A.P.B., Osuna-Castro, J.A., Utsumi, S., Mikami, B., Maruyama, N. 2012. Crystal structure of a major seed storage protein, $11 \mathrm{~S}$ proglobulin, from Amaranthus hypochondriacus: Insight into its physico-chemical properties. Food Chemistry 135, 819-826.

Tatham, A.S., Field, J.M., Morris, V.J., I'Anson, K.J., Cardle, L., Dufton, M.J., Shewry, P.S., 1993. Solution conformational analysis of the $\alpha$-zein proteins of maize. The Journal of Biological Chemistry $268,26253-26259$.

Tatham, A.S., Fido, R.J., Moore, C.M., Kasarda, D.D., Kuzmicky, D.D., Keen, J.N., Shewry, P.R., 1996. Characterisation of the major prolamins of tef (Eragrostis tef) and finger millet (Eleusine coracana). Journal of Cereal Science 24, 65-71. 
Taylor, J., Taylor, J.R.N,. 2011. Protein biofortified sorghum: Effect of processing into traditional African foods on their protein quality. Journal of Agricultural and Food Chemistry 59, 2386-2392. Taylor, J., Anyango, A.O., Taylor, J.R.N., 2013a. Developments in the science of zein, kafirin and gluten protein bio-plastic materials. Cereal Chemistry 90, 344-357.

Taylor, J., Taylor, J.R.N., Belton, P.S., Minnaar, A., 2009 Formation of kafirin microparticles by phase separation from an organic acid and their characterization. Journal of Cereal Science 50, 90-105. Taylor, J.R.N., Dlamini, B.C., Kruger, J., 2013b. The science of the tropical cereals sorghum, maize and rice in relation to lager beer brewing. Journal of the Institute of Brewing 119, 1-14.

Taylor, J.R.N., Belton, P.S., Beta, T., Duodu K.G., 2014. Review: Increasing the utilisation of sorghum, millets and pseudocereals: Developments in the science of their phenolic phytochemicals, biofortification and protein functionality. Journal of Cereal Science 59, 257-275.

Utsumi , S,. 1992. Plant food protein engineering. Advances in Food Nutrition Research 36, 89-208. Vallons, K.J.R., Ryan, L.A.M., Arendt, E.K., 2011. Promoting structure formation by high pressure in gluten-free flours. LWT-Food Science and Technology 44, 1672-1680.

Vallons, K.J.R., Ryan, L.A.M., Koehler, P., Arendt, E.K., 2010. High pressure-treated sorghum flour as a functional ingredient in the production of sorghum bread. European Food Research and Technology $231,711-717$.

Van Vliet, T., 2008. Strain hardening as an indicator of bread-making performance: a review with discussion. Journal of Cereal Science, 48, 1-9.

Wang, Y., Padua, G.W., 2012. Nanoscale characterization of zein self-assembly. Langmuir 28, 24292435.

Watterson, J.J., Shull, J.M., Kirleis, A.W., 1993. Quantitation of $\alpha-, \beta-$, and $\psi$-kafirins in vitreous and opaque endosperm of Sorghum bicolor. Cereal Chemistry 70, 452-457.

Wen, T-N., Luthe, D.S., 1985. Biochemical characterization of rice glutelin. Plant Physiology 78, 172177. 
Wolter, A., Hager, A-S., Zannini, E., Czerny, M., Arendt, E.K. 2014. Impact of sourdough fermented with lactobacillus plantarum FST 1.7 on baking and sensory properties of gluten-free breads. . European Food Research and Technology 239, 1-12.

Wu, Y.V., Paulis, J.W., Sexson, K.R., Wall, J.S., 1983. Conformation of corn zein and glutelin fractions with unusual amino acid sequence. Cereal Chemistry 60, 342-344.

Yamagata, H., Sugimoto, T., Tanaka, K., Kasai, Z., 1982. Biosynthesis of storage proteins in developing rice seeds. Plant Physiology 70, 1094-1100.

Yano., H., 2010. Improvements in the bread-making quality of gluten-free rice batter by glutathione. Journal of Agricultural and Food Chemistry 58, 7949-7954.

Yong, Y. H., Yamaguchi, S., Gu, Y.S., Mori, T., Matsumura, Y., 2004. Effects of enzymic deamidation by protein-glutaminase on structure and functional properties of $\alpha$-zein. Journal of Agricultural and Food Chemistry 52, 7094-7100.

Zhang, B., Luo, Y., Wang, Q., 2011. Effect of acid and base treatments on structural, rheological and antioxidant properties of $\alpha$-zein. Food Chemistry 124, 210-220.

Zhang, W., Sangtong, V., Peterson, J., Scott, M.P., Messing, J., 2013. Divergent properties of prolamins in wheat and maize. Planta 237, 1465-1473. 